NBER WORKING PAPER SERIES

\title{
EARLY ACADEMIC SCIENCE AND THE BIRTH OF INDUSTRIAL RESEARCH LABORATORIES IN THE U.S. PHARMACEUTICAL INDUSTRY
}

\author{
Megan MacGarvie \\ Jeffrey L. Furman \\ Working Paper 11470 \\ http://www.nber.org/papers/w11470
NATIONAL BUREAU OF ECONOMIC RESEARCH 1050 Massachusetts Avenue
Cambridge, MA 02138
June 2005

We thank Claudia Goldin for data from the Biennial Survey of Education for 1924 and 1934 . We are also grateful to Henan Cheng for her excellent RA work. Scott Stern provided inspiration for the project and insightful suggestions throughout; Bronwyn Hall, Zorina Khan, Petra Moser, David Mowery, Toby Stuart, and Sam Thompson contributed helpful suggestions. We are particularly grateful participants in the NBER Conference on Academic Entrepreneurship and Innovation, to Adam Jaffe, Josh Lerner, Marie Thursby, Scott Stern fororganizing the conference, and to Ken Sokoloff for insightful discussant commentary. Megan MacGarvie gratefully acknowledges support from the Center for Studies in Higher Education and the John M. Olin Foundation and Jeff Furman gratefully recognizes support from the Boston University Junior Faculty Research Fund. We would like to note that aspects of the case histories of Sterling and Mulford (Section III.2) re also described in Furman (2003). The views expressed herein are those of the author(s) and do not necessarily reflect the views of the National Bureau of Economic Research.

(C2005 by Megan MacGarvie and Jeffrey L. Furman. All rights reserved. Short sections of text, not to exceed two paragraphs, may be quoted without explicit permission provided that full credit, including (C) notice, is given to the source. 
Early Academic Science and the Birth of Industrial Research Laboratories in the U.S.

Pharmaceutical Industry

Megan MacGarvie and Jeffrey L. Furman

NBER Working Paper No. 11470

June 2005

JEL No. O32, N00

\section{$\underline{\text { ABSTRACT }}$}

The establishment and growth of industrial research laboratories is one of the key organizational innovations affecting technological progress in the United States in the 20th century. In this paper, we investigate the rise of industrial research laboratories in the U.S. pharmaceutical industry between 1927 and 1946. Our evidence suggests that institutional factors, namely the presence of universities dedicated to research, played a significant role in the establishment and diffusion of private pharmaceutical research laboratories. Specifically, we document that the growth of industrial pharmaceutical laboratories between 1927 and 1946 is positively and significantly correlated with the extent of local university research, after controlling for other observable factors likely to influence the geographic distribution of industrial research. We supplement our core results with case histories illustrative of early university-industry interaction and an examination of the determinants of university-industry research cooperation. Our qualitative historical evidence and analyses of the birth of chemical engineering programs suggest that industry also played a role in influencing university research agendas. We correct for feedback effects from industry to universities using instrumental variables. Overall, our analyses suggest that while the presence of industrial facilities helped shape the direction of university research programs, there was a significant, positive, and causal effect running from university research to the growth of pharmaceutical research laboratories in the first half of the twentieth century in the United States.

Megan MacGarvie

Boston University

School of Management

595 Commonwealth Avenue, Room 522H

Boston, MA 02215

and NBER

mmacgarv@bu.edu
Jeffrey L. Furman

Boston University

School of Management

595 Commonwealth Avenue, Room 522H

Boston, MA 02215

and NBER

furman@bu.edu 


\section{Introduction}

The establishment and growth of industrial research laboratories is one of the key organizational innovations affecting technological progress in the United States in the $20^{\text {th }}$ century (Mowery, 1990). We investigate in this paper the rise of industrial research laboratories in the U.S. pharmaceutical industry between 1927 and 1946. Our evidence suggests that universities played a significant role in the establishment and diffusion of industrial research laboratories in the U.S. pharmaceutical industry during this period. The foundation of our quantitative analysis is the demonstration that the emergence and growth of private pharmaceutical research laboratories depends upon the extent and growth of nearby academic science. We complement the quantitative results with qualitative evidence that elucidates some of the mechanisms by which universities and industry interacted during this period. For example, our qualitative analyses demonstrate evidence of universityindustry collaboration involving prominent academics, considerable academic participation in industrial patenting, and the staffing of emerging industrial research laboratories with graduates of nearby university programs. We are also alert to the fact that this relationship may not have been unidirectional, and devote particular attention to the possibility that the local industrial base affected the nature of academic science at universities during this period. Our analyses provide suggestive though not dispositive evidence of the impact of local firms on university programs. Even when we correct for this endogeneity bias, however, the result that laboratory births are positively related to $\mathrm{PhD}$ program graduates remains. We interpret this combination of qualitative and quantitative evidence as support for the hypothesis that universities played a significant role in the birth of early American pharmaceutical research laboratories. 
Hand-in-glove relationships between firm laboratories and universities in the life sciences are commonplace in the early 2000 s, but were substantially more rare a century ago. Indeed, many academic scientists and academic bodies viewed industry with extreme skepticism or overt antipathy. Quoting a 1915 report of the Committee of the Board of Trustees of the American Medical Association, Parascandola (1985) illustrates the contempt held by medical scientists for industry: "It is only from laboratories free from any relations with manufacturers that real advances can be expected." Though a fictional tale, Sinclair Lewis's novel Arrowsmith is more severe but also representative of the attitude of the time. Reacting to the news of famed biology professor Max Gottlieb's decision to join the research laboratories of a private firm, colleagues grieved: In one lab, "sorrowing men wailed, 'How could old Max have gone over to that damned pill peddler?,"' while in other places colleagues lamented, "Of all the people in the world! I wouldn't have believed it! Max Gottlieb falling for those crooks!," and "I wish HE hadn't gone wrong!" (Lewis, 1925, p. 52). ${ }^{2}$ It is, then, somewhat surprising that an environment that harbored such scorn for industry would, ultimately, be actively involved in planting the seed corn for the development of industrial research laboratories.

History demonstrates, however, that Prof. Gottlieb's decision to work with the pill peddlers was emblematic of the growing ties between university scientists and private firms in the U.S. pharmaceutical and chemical industries during this time period. Indeed, while, "American drug companies by and large had no interest in research [in the early years of the $20^{\text {th }}$ century,]" (Swann, 1990, p.77), industrial research laboratories grew throughout the

1 This quote appears in the Journal of the American Medical Association (1915) "Special Report of the Work of the Council on Pharmacy and Chemistry," 65, p. 69.

2 This quote is used commonly among historians of the U.S. pharmaceutical industry to reflect the attitudes of the time. See, for example, Parascandola (1985), Swann (1990), and Liebenau et al. (1990). 
1920s and 1930s such that they were a common organizational form among large pharmaceutical manufacturers by the time of World War II. The increasing relevance of academic science for industrial purposes in the late $19^{\text {th }}$ and early $20^{\text {th }}$ centuries appears to have been a principal underlying force that enabled collaborations between universities and industry to be ultimately fruitful (Mowery and Rosenberg, 1998; Murmann, 2003). We argue that the existence of U.S. universities (and their specific form and nature) animated the potential for interaction between academic scientists and pharmaceutical firms in the U.S. interwar period. We examine the early mechanisms through which universities affected research in the pharmaceutical and chemical industries and devote particular attention to the labor market for trained researchers, collaborative research and consulting agreements, and contract research arrangements. ${ }^{3}$ While our primary aim is to ascertain the extent and nature of university influence on the development of industrial research laboratories, we also examine the extent to which university researchers and their institutions were affected by their interactions with industry. Some qualitative evidence suggests that large pharmaceutical companies with substantial research needs did, indeed, influence proximate universities, and our statistical analyses provide some evidence consistent with this phenomenon.

In our principal analysis, we assesses the relationship between academic science and the establishment of pharmaceutical research laboratories by estimating the impact of the presence of universities and the count of $\mathrm{PhD}$ graduates on the number of industrial pharmaceutical laboratories established and number of pharmaceutical $R \& D$ workers in geographically proximate areas. We set the stage for this analysis by reviewing case

\footnotetext{
${ }^{3}$ The importance of collaborative research between academic scientists and drug makers is of central interest in the industrial histories of John P. Swann $(1988,1990)$.
} 
histories of early U.S. pharmaceutical firms and describing the nature of relationships between academic scientists and pharmaceutical firms. The empirical evidence reveals that pharmaceutical labs were more likely to be located in counties that contained research in academic chemistry or science. Specifically, the number of pharmaceutical laboratories in a county in 1938 and 1947 is, across a wide range of specifications, positively and significantly associated with the initial number of research laboratories and the contemporaneous count of local science $\mathrm{PhD}$ graduates.

Building on the quantitative analyses, we clarify some of the mechanisms by which universities appear to have influenced the birth of pharmaceutical research laboratories. In particular, drawing on records from the rosters of Who's Who in Chemistry (1928), we demonstrate the involvement of adopting firms in the labor market for graduating PhDs. Further, we present evidence that collaborative arrangements between academic scientists and industry and, occasionally, contract research agreements were both important precursors and complements to firms developing their own laboratories. Combining patent data with data from American Chemical Society membership rosters, we find that a substantial share of pharmaceutical patents for which we can identify inventor affiliations included academic inventors.

Overall, our results paint a picture in which the role of universities in the development of industrial research laboratories is significant and multifarious. In addition to serving as the launching pad for the careers of individuals who found employment in private firm laboratories, U.S. universities appear to have played a role in the creation of such laboratories, via collaborative research and consulting, and in their developing expanded research capabilities over time. We also cite qualitative evidence of feedback effects from 
firms to universities. By both providing financial support for university research laboratories and a market for future trained labor, firms supported the growth of scientific capabilities at local universities. The relationships between Merck and Rutgers and Dupont and the University of Delaware are illustrative of the bi-directional impact of the relationship between universities and industry. Our analysis of the birth of chemical engineering programs provides evidence consistent with these qualitative accounts. Our core results about the influence of universities on the birth of research laboratories do, however, hold up, even after correcting for endogeneity using instrumental variables.

The remainder of the paper proceeds in the following way: Section 2 introduces background research on university-industry interaction and reviews the history of the pharmaceutical industry in the early $20^{\text {th }}$ century, and the origins of industrial research laboratories. Section 3 reviews historical interactions between the U.S. pharmaceutical industry and academic science. Section 4 describes our core dataset. Section 5 evaluates the importance of universities in influencing the growth of pharmaceutical research laboratories. Section 6 assesses the mechanisms of interaction between universities and pharmaceutical firms in greater detail. Section 7 reviews quantitative evidence on the role of industry in affecting program births in universities. Section 8 discusses our instrumental variables estimates. Section 9 concludes, discussing the implications of the results and speculating regarding related, future research.

\section{University-Industry Interaction and the Origin of Industrial Research Laboratories}

In this section, we lay the groundwork for our argument that U.S. universities contributed to the establishment and growth of industrial research laboratories. In particular, 
we review research that describes the growth of the U.S. universities in the late 1800 s and early 1900s, suggests the importance of universities to the United States' emerging industrial leadership, and suggests that proximity and specific institutional arrangements played an important role in university-industry interaction.

\section{II.1 The emergence of U.S. universities and the nature of university-industry interaction}

Goldin and Katz (1999) identify the period of 1890-1940 as the "formative years" of American higher education. States dramatically increased their support of higher education during this period and the U.S. research university emerged in a form similar to that which exists today. These years were also formative for university-industry collaboration and the rise of industrial research laboratories in the United States. Figures 1-3 display the number of public universities, private universities, and industrial research labs by founding date, beginning in 1830 . They reveal that more universities were founded in the late $19^{\text {th }}$ century than in any other period. In large part, the rise of universities was due to the Morrill Act of 1862, which established the land-grant universities, and the Hatch Act of 1887, which provided aid for the study of scientific agriculture. The emergence of industrial research labs came somewhat later, in the 1920 s and 1930s. ${ }^{4}$ The boom during this period was, however, quite substantial, so substantial in fact that university-industry interaction reached a high point in the period between World War I and World War II. As Mowery and Rosenberg (1998) note, "university-industry research linkages... were well-established

4 It should be taken into account that these graphs are snapshots taken at two different points in time: the university data were compiled in 1924 and the industrial research lab survey was conducted in 1946. As a result, firms that were founded prior to 1946 but did not survive to that date are not counted. 
before World War II. Indeed, the share of university research expenditures financed by industry appears to have declined throughout much of the postwar period" (p. 37). ${ }^{5}$

Rosenberg, Mowery, Nelson and a number of co-authors have argued that the research universities that emerged during this period - and, in particular, the aspects of academic science that responded to the needs of industry - became one of the main drivers of American technological leadership in the twentieth century. ${ }^{6}$ These authors note a number of examples of commercially important early inventions that originated in universities, including the Babcock test (which improved the way dairy producers tested the butterfat content of milk); Edwin Armstrong's research on vacuum tubes at Columbia University (which influenced the development of radio technology); and the development of hybrid corn at agricultural experiment stations. ${ }^{7}$ Noting the important influence on innovation in the later part of the $20^{\text {th }}$ century, these authors further acknowledge the seminal contributions of university research on the development of computers and lasers (Rosenberg and Nelson, 1994; Mowery et al., 2003, p. 1).

The role of proximity in facilitating university-industry linkages is central in our investigation of the factors that led to the rise of industrial research laboratories. Existing empirical studies of contemporary university-industry research linkages suggest that research conducted in universities has a significant and geographically focused effect on innovation. Jaffe (1989) provides evidence that corporate patenting in certain industries is

5 Also, Swann (1988) argues that post-war increases in federal funding for university research in the health sciences reduced collaboration between universities and the pharmaceutical industry.

6 See Nelson and Wright (1992), Rosenberg and Nelson (1994), Mowery and Rosenberg (1998), Rosenberg (2000), Mowery, Nelson, Ziedonis and Sampat, (2003).

7 As another example, the University of Akron supplied local rubber producers with skilled employees, and its scientists conducted research in the processing of rubber and, later, polymer chemistry (Mowery et al., 2003), p. 1). Additional examples include the University of Oklahoma's research in the field of petroleum, the University of Kentucky's and the University of North Carolina's focus on the processing of tobacco, and the University of Illinois and Purdue University's work on railroad technologies (Nelson and Rosenberg, 1994). 
positively associated with state-level spending on university research in related academic disciplines. Acs, Audretsch and Feldman (1992) substitute innovation counts for patent data and find even stronger evidence for spillovers from university research. Jaffe, Trajtenberg, and Henderson (1993) find that knowledge spillovers from university research, as measured by patent citations, are geographically concentrated. ${ }^{8}$ In a study of the biotechnology industry, Zucker, Darby and Brewer (1998) show that biotechnology firms tend to locate near universities in order to take advantage of the areas' higher levels of "intellectual capital". In both the qualitative and quantitative evidence we review, geographic proximity plays an important role in facilitating interactions between universities and pharmaceutical firms.

The nature of university-firm interactions is informed by research that examines the organizational locus of innovative activity. Specifically, a set of recent papers examine whether innovative activity takes place in divisions of the corporation or in entrepreneurial firms that transact in the market for technology. Teece (1988) explains how transaction costs can dictate the organizational form in which innovation takes place. Arora, Fosfuri and Gambardella (2001) document the growth in technology trade in the late twentieth century, led by high-tech industries like software, chemicals, semi-conductors and electronics. Arora, Fosfuri and Gambardella (2003) model the division of "inventive labor" under different conditions. Stern and Gans (2003) focus on how several aspects of the "commercialization environment" affect the innovative start-up's optimal choice of cooperation or competition with incumbent firms. Peretto (1998) develops a model that explains the transition from independent inventors to corporate $R \& D$ labs in the late

\footnotetext{
${ }^{8}$ Patent citations are references in the patent document to other patented technologies that bear a similarity to the invention or that influenced the inventor. Note that Adams (2002) also finds evidence of geographicallymediated university spillovers.
} 
$19^{\text {th }} /$ early $20^{\text {th }}$ centuries as a product of the "interaction of market structure and technological change.”

\section{II.2 The origins of industrial research}

The first organized industrial research laboratories appeared in Germany in the 1870 s, in firms that sought to commercialize inventions based on recent breakthroughs in organic chemistry (Mowery and Rosenberg, 1998, p. 13.). Murmann (2003) describes the co-evolution of the dye industry and academic research in chemistry in nineteenth-century Germany, and argues that spillovers from universities to the dye industry and vice versa led Germany to dominate the international dye industry in the $19^{\text {th }}$ century. Mowery and Rosenberg argue that it was not scientific developments alone which led to the growth of inhouse research in the United States, but also the strength of U.S. anti-trust policy following the Sherman Act (which triggered a search for alternative sources of market power through industrial innovation) and stronger protection of intellectual property rights through the patent system. However, as Mowery points out, "a weak antitrust climate in other nations, such as Germany, was associated with growth in industrial research, making it difficult to assert a direct cause-and-effect relationship between anti-trust policy and the growth of intrafirm R\&D” (Mowery, 1990, p. 346). It could also be argued that the increasing strength of intellectual property rights in the late $19^{\text {th }}$ and early $20^{\text {th }}$ centuries would seem to promote greater specialization in innovation and vertical dis-integration rather than a shift in innovative activity from the realm of the independent inventor to within the boundaries of the corporation. Indeed, Lamoreaux and Sokoloff (2002) argue that, in the nineteenth century, 
"the U.S. patent system created a framework that supported trade in technology, and that the patent agents and lawyers who serviced this system often took on the functions of intermediaries, matching inventors seeking capital with investors seeking profitable outlets for their funds and also inventors seeking to sell new technological ideas with buyers eager to develop and commercialize them" (p. 5$6)$.

Lamoreaux and Sokoloff (1996) document a well-functioning market for technology in the late nineteenth century United States. In 1870-71, for example, $72 \%$ of all patents that were assigned to a party other than the inventor were assigned after issue. By 1910-11, this number was halved (36.5\%). Fisk (1998) explains that, prior to the 1890 s, courts almost always favored the rights of the inventor in cases where the ownership of an employee's invention was contested by an employer. Starting in the 1890s, Fisk documents the emergence of the "shop right" patent doctrine, which favored the employer in intellectual property disputes. This change in intellectual property doctrine no doubt made it much more attractive for firms to establish in-house research labs.

Mowery and Rosenberg also emphasize the importance to industrial innovation of science conducted in universities. In this paper, we argue that the unique form taken by American universities in the late nineteenth and early twentieth centuries helped promote the adoption of industrial research laboratories within the boundaries of firms. Whereas during the nineteenth century, "most industrialists believed the manufacturer's job was to manufacture; new ideas to improve manufacturing could be purchased or otherwise appropriated ... managers offered little support for research until they had evidence that a worker's results indicated likely commercial application," (Swann, 1988, p. 13) the institutionalization of scientific research in universities facilitated the adoption of scientific research in industry. The scientific research undertaken in universities reduced the cost to firms of acquiring scientific knowledge, and this led firms located near universities to 
engage in research. Furthermore, the trend towards specialization and professionalization in science increased the supply of qualified workers with easily identifiable skills. Once firms could access a pool of potential research workers whose academic credentials reduced the uncertainty associated with hiring them, firms could establish labs to engage in long-term research projects.

Several interrelated historical forces combined to favor the organization of invention within the firm. Changes in the nature of technology, in the extent to which firms could claim intellectual property rights over their employees' inventions, and in the enforcement of anti-trust rules contributed to firms seeking to adopt of in-house industrial research facilities. In order for firms to respond to these forces to organize invention within firm boundaries, they needed skilled R\&D workers and scientific expertise. Universities provided these inputs to production of new technology through consulting relationships and by providing certification for the skills of potential R\&D employees.

\section{The U.S. Pharmaceutical Industry and Academic Science in the Early 20 Century}

III.1. Research in the pharmaceutical industry in the early $20^{\text {th }}$ century

Although a select number of pharmaceutical firms employed in-house researchers in the early years of the $20^{\text {th }}$ century, the period between the 1920 and World War II witnessed a substantial change in the organization and function of U.S. drug makers (Swann, 1988). Over this period, the industry changed from consisting of nearly entirely manufacturingoriented firms to being largely comprised of firms dedicated to the systematic discovery and introduction of efficacious medicines. Some of the changes in the industry were preceded or accompanied by legislative changes, such as the Biologics Control Act of 1902 and Pure 
Food and Drug Act of 1906 (and 1912 Shirley Amendment), each of which pushed the industry away from sometimes fraudulently-labeled 'patent' medicines towards more rationalized practices.

In addition to US-based characteristics and policies, Europe played an important role in aiding American firms in their transition to science-based pharmaceutical research. In the years prior to World War I, European-trained (mainly German-trained) researchers and students returned to the United States, often to Philadelphia, New York, and the region inbetween (Feldman and Schreuder, 1996) offering expertise, particularly in biologics, to pharmaceutical firms, universities, and public health administrations. The development of research capabilities in U.S. pharmaceutical firms was further accelerated by World War I. The loss of access to European medicines increased the need for national medicine-making capabilities, and the ability to develop medicines was enhanced both by European immigration and by the seizure and auction of German intellectual property by the Office of the Alien Property Custodian.

These developments were concomitant with an increasing relevance of academic science for drug-making during late 19th and early 20th centuries, which in the eyes of Mowery and Rosenberg (1998) and Murmann (2003) helped set the stage for fruitful collaborations between universities and industry and, as we argue, for the US pharmaceutical industry to draw on resources in universities to help develop in-house research facilities. From the early part of the century, during which research and development expenditures were minimal, Mahoney (1959, p. 4) reports that research expenditures increased to $\$ 15$ million in 1939 and $\$ 110$ million by 1956 . Mahoney claims that the nature of the pharmaceutical industry changed dramatically during the 1930 s and 
1940s, as a result of increasing average firm size and technical sophistication. For example, he reports that during the depression years of 1932 and 1934, more than 3,500 firms failed (p. 4) and that even until the 1940s most firms were quite small: “As late as 1939 no ethical drug manufacturer in America had a sales volume as large as a department store like Macy's in New York" (p. 4).

Although the nature of the industry was already changing by the early 1940s, the loss, once again, of medicines from Europe and the exigencies of war prompted significantly increased investment in research during World War II. For the first time, the U.S. government became actively involved in promoting drug development and manufacturing. Two major projects in which the government played a large role were the production of penicillin and dried plasma. These projects were mainly dedicated towards large-scale manufacturing, but significant $R \& D$ capabilities were a pre-requisite for achieving the knowledge to effectively produce the products, and those firms that had already achieved some level of in-house research expertise were at considerable advantage.

III.2. Historical evidence of the influence of early $20^{\text {th }}$ century academic science on pharmaceutical research

In order to characterize the relationship between academic science and the early industrial research labs, we exploit the fact that geographic proximity facilitates interaction between people and organizations. We argue that firms located near research universities were more likely to adopt in-house $R \& D$ facilities because local universities provided both part-time faculty consultants with highly specialized knowledge and scientifically-trained university graduates who could be employed as full-time research employees. Because long-distance collaboration was more difficult in the first half of the twentieth century than 
it is today, firms were more likely to focus their search for scientific expertise on nearby institutions. In this section, we discuss histories of a number of early pharmaceutical firms, including Mulford and Sterling, whose cases appear illustrative of the influence of local university science on firm-specific investments in innovation. ${ }^{9}$

III.2.1 Illustrative Cases - Mulford \& Sterling at the turn of the $20^{\text {th }}$ century

Founded by two graduates of the Philadelphia College of Pharmacy, the H.K. Mulford Company commenced operations in Philadelphia in 1891 when H.K. Mulford and Milton Campbell purchased the "Old Simes" drugstore. After initial successes in improving pill-making technologies, the founders undertook a more ambitious challenge for which they themselves were by no means sufficiently trained - the synthesis of diphtheria antitoxin. Bacteriological illness had become increasingly problematic for urban areas as a result of the increased density of city life. This problem was of particular concern to the Municipal Health Department in Philadelphia, which was the third largest city in the country at the time. Philadelphia's Health Department, like that of New York, was especially active in promoting efforts to address bacteriological illnesses. Long known as the "Cradle of Pharmacy" (Mahoney, 1959; Feldman and Schreuder, 1996), Philadelphia was the home to some of the most advanced biomedical research institutions in North America. In addition to the Philadelphia College of Pharmacy, several other institutions were pursuing bacteriological research, including the University of Pennsylvania, Medico-Chirurgical College, and Pepper Clinical Laboratories of the University Hospital. Together with the Municipal Health Department, these institutions were engaged in research on diphtheria in response to "public clamor" for a diphtheria antitoxin (Galambos, 1995, p. 13). Galambos

\footnotetext{
${ }^{9}$ Furman (2003) reviews the relationship between local resources and the strategic orientation of Mulford and Sterling.
} 
argues that Mulford "recognized the opportunities embodied in the "clamor" for diphtheria antitoxin" and set out to produce a commercially viable drug (Galambos, 1995, p. 13). In 1894, the firm hired Dr. Joseph McFarland, who was on faculty at the University of Pennsylvania's Medical Department and the Philadelphia Polyclinic and College for Graduates in Medicine and had trained in bacteriology in Heidelberg and Vienna, and created for him a laboratory in which he could concentrate on developing diphtheria antitoxin (Galambos, 1995). In his efforts, McFarland benefited greatly from interactions with the New York City Health Department and the Laboratory for Hygiene at the University of Pennsylvania. By 1895, Mulford was able to become the first commercial provider of a diphtheria anti-toxin. The firm's success with McFarland then led them to hire Professor Leonard Pearson from Penn's Veterinary School and to establish a full-fledged laboratory in 1896 in Glenoden, PA dedicated to biological, veterinary, and vaccine research (Galambos, 1995). In the absence of these locally-available academic scientific resources, it does not appear as if Mulford would have engaged the task of synthesizing diphtheria antitoxin or, ultimately, of founding a dedicated research laboratory.

The Sterling pharmaceutical company was founded under circumstances similar to those of Mulford and around the same point in time, yet it pursued a very different trajectory with respect to research. Upon graduation from the Philadelphia College of Pharmacy, the same institution attended by the founders of Mulford, William E. Weiss returned to his hometown of Wheeling, West Virginia and founded the company that became Sterling in conjunction with his childhood friend Albert Diebold. Like Mulford, the fledgling drugmaker met with considerable success; unlike Mulford, however, the firm succeeded at marketing and distributing patent medicines, products of questionable medical validity 
which were often alcohol- or narcotic-based. By 1912, it was valued at \$4 million (Mann and Plummer, 1991). In the wake of World War I, Sterling acquired the assets of the Bayer Company, including all U.S. rights to Bayer Aspirin in the auction of seized German property rights held by the Office of the Alien Property Custodian. That the fact that Sterling was able to raise the funds required for this acquisition demonstrates the triumph of the firm's marketing and distribution resources. Its technical and research capabilities were substantially less well-developed, however. Sterling's drug-making competence was, in fact, so limited that it was forced to solicit substantial guidance from Bayer in order to have any chance to manufacture the basic products it won at auction.

Both demand and supply side factors appear to have had an influence on Sterling's choice of organizing strategies. Serving the mainly rural populations of West Virginia and central and western Pennsylvania, Sterling did not face substantial demand for medicines to fight the bacteriological illnesses towards whose cures academic science had begun to work. Even if such demand had existed, however, Sterling did not have ready access to trained individuals who could have contributed to effectively to drug discovery; at the very least, it seems fair to say that the comparative advantage of Sterling's West Virginia location was not based in scientific research.

While stylized, these stories seem to be illustrative rather than unique. The early history of Detroit's Parke-Davis, another one of the first chemical firms to establish sciencebased industrial research, resonates with that of Mulford. Similar to its Philadelphia counterpart, Parke-Davis began serious research efforts with the aim of making diphtheria anti-toxin. To do so, it hired Elijah M. Houghton, a research assistant at the nearby University of Michigan in 1895 and Charles McClintock, a research assistant in 
bacteriology, in 1896 (Swann, 1988). Parke-Davis established a research lab in biology, and succeeded in producing diphtheria anti-toxin within a few months. McClintock then turned his efforts to other biological research, which dominated the firm until the 1920s when a separate department for chemical research was established (Swann, 1988).

These early examples of the importance of local labor markets in diffusing biomedical research knowledge are typical of the experience of U.S. firms in the 1920s and 1930s. Firms located near universities appear to have had greater ease in recruiting scholars for their research efforts. The differences in the strength and relevance of the science bases in Philadelphia, PA and Wheeling, WV during the formative years of Mulford and Sterling are vast. The "Cradle of Pharmacy," Philadelphia was home to numerous universities with departments dedicated to biomedical sciences, including the University of Pennsylvania (which was founded 1740, and offered its first doctorate in 1871), as well as the Philadelphia College of Pharmacy (founded 1821), the Medical College of Pennsylvania (1850), Jefferson Medical College (1825), Hahnemann Medical College (1848), Temple University (1884), and the Drexel Institute of Technology (1892). The University of Pennsylvania was one of the country's leading biomedical institutions, and had granted, on its own, 919 doctorates by 1925. By contrast, Sterling's hometown, Wheeling, WV was 50 miles from the nearest university. The closest large universities to its home base were in Pittsburgh (59 miles from away), Morgantown, WV (79 miles away), and Penn State (198 miles away). Though not immediately nearby, Pittsburgh was an emerging center of university life at the turn of the century, offering the University of Pittsburgh (which was founded in 1786 and granted its first doctorate in 1886), the Carnegie Institute of Technology (founded 1905), and Duquesne University (founded 1878). However, even if Sterling had opened facilities 
in Pittsburgh, these growing universities would not have been able to offer research services comparable to those of Philadelphia - by 1925, the city's largest university, the University of Pittsburgh, had only granted $86 \mathrm{PhDs}$, and Carnegie and Duquesne did not grant any PhDs until the 1920s.

III.2.2. Early university-industry interactions - collaborations \& local labor markets

In this section we review historical evidence that suggests that university academics were sought-after collaborators for early research labs, and that suggests that geographic propinquity played an important role in the ability to collaborate with university-based researchers. Both the importance of some academic collaborators and the potentially prohibitive cost of long-distance collaboration are illustrated by the agreement struck between $\mathrm{Du}$ Pont and consulting chemist Roger Adams, a professor at the University of Illinois. Du Pont offered Adams $\$ 5,000$ a year, which was substantially more than half his university salary, to entice him to make a monthly trip from Urbana to Wilmington, and to visit for a month or so during the summers. Adams negotiated a deal in which he received $\$ 3,000$ annually (plus travel expenses) for a visit every other month, along with $\$ 750$ for each summer month spent at Du Pont (Hounshell and Smith, 1988). ${ }^{10}$ While Du Pont, one of the first and most successful companies to adopt in-house research, had access to the funds required to invest in long-distance relationships with consultants (and had little choice, given the absence of a major research university in the vicinity of Wilmington), younger and smaller firms did not. Table 1 lists the industrial labs in the National Research Council (NRC) data that in 1938 listed the names of the universities at which they funded consultants

\footnotetext{
${ }^{10}$ While a consultant for Du Pont, Adams told a colleague, "I feel that I get quite as much out of the contact from the chemical standpoint as they do" (Ibid, p. 298).
} 
or research fellows. ${ }^{11}$ Local universities, where they exist, predominate. While other more distant universities were supported by firms with larger research efforts (like Merck, with a research staff of 111), even these firms continue to be associated with nearby universities.

Universities, in addition to providing consulting services, fed the labs with a supply of skilled labor. We have seen that Mulford and Parke-Davis both hired graduates of local universities (the University of Pennsylvania and the University of Michigan, respectively) to form two of the first in-house research labs in the United States. Looking at a larger sample, we draw on evidence of the geographic mobility of university graduates from the Chemical Who's Who, a directory published in 1928 that contains biographical sketches of executives and researchers in the chemical industry. For a sample of the thirty largest labs in the National Research Council (NRC) volume of 1927, we collected information on the educational background and location of first employment of executives listed in the Who's Who. Many of the executives, whether directly involved in research or not, came from scientific backgrounds, and the biographical information on the location of an individual's alma mater and post-graduate employment is instructive whether or not the individual joined the company immediately upon graduation. The information we collected revealed that the first employment after graduation from a university was very often in the same city as the university, and that many firms seemed to hire graduates of nearby universities. While the extent of this practice varied by firm, the firms that did hire from nearby universities ("nearby" defined loosely to include universities within 100 or 200 miles of the lab) tended to hire almost exclusively from those universities. For example, at Sharp and Dohme of Baltimore, one of the two directors of pharmaceutical research listed in the Who's Who in

\footnotetext{
${ }^{11}$ In the NRC publication, this is described as "grants to university labs for research projects in support of program of association."
} 
1928 was J.C. Krantz, a former professor at the University of Maryland and a former lecturer at Johns Hopkins. The other director of pharmaceutical research graduated from the Philadelphia College of Pharmacy and had worked at Mulford and Co. in Philadelphia before joining Sharp and Dohme. One laboratory superintendent (C. Neal) was a graduate of the University of Maryland department of Pharmacy, and another superintendent (E. Miller) earned a doctorate from Johns Hopkins. Of the nine employees and executives whose educational credentials are described in the Who's Who, six joined after studying or working at Johns Hopkins or the University of Maryland. Three were graduates of the Philadelphia College of Pharmacy (two of whom came to Sharp \& Dohme after initial employment at Mulford \& Co) and one came to Sharp \& Dohme after working as a professor at the University of Vermont. ${ }^{12}$

Another example of localization in early research collaborations, Eli Lilly \& Co., of Indianapolis, Indiana, engaged in collaborative research with Purdue University. Lilly hired Purdue grads, like director of research development H.W. Rhodehamel, chief pharmacist F.E. Bibbins, and assistant chief engineer J.C. Siegesmund. Pharmaceutical research scientist E.H. Stuart was a graduate of Indiana University. The majority of Lilly employees whose credentials are listed in the Who's Who were graduates of Indiana universities. Of the ten listed university-educated employees of Eli Lilly \& Co. of Indianapolis, four were graduates of Purdue University (62 miles away in West Lafayette) who joined Lilly upon graduation. Two attended other universities in Indiana (DePauw and Indiana University), one came from the U.S. Industrial Alcohol Co. in New Orleans after graduating from Louisiana State University, and the others studied at Trinity College and the Philadelphia

\footnotetext{
${ }^{12}$ Sharpe and Dohme acquired Mulford around this time (officially, 1929; Galambos, 1995), which may explain the number of Sharpe and Dohme executives that Who's Who credits with Mulford experience.
} 
College of Pharmacy. As we discuss in some more detail below, Lilly also provides an interesting example of early firms' abilities to work with distant researchers.

At Abbott Labs of Chicago, the president, Alfred Burdick, was a former professor at the Illinois Medical College; consulting scientist Roger Adams was chair of the department of Chemistry at the University of Illinois Urbana-Champaign. Adams' former student, Henry Volwiler, chief chemist in 1928 (later president and chairman of the board), was a graduate of the University of Illinois, as was Floyd Thayer, a former research chemist who was in 1928 manager of the chemical sales department. Of the eight people listed, six joined the firm after graduating from or working at an Illinois university. Swann notes that several of Adams' students also went on to join Abbott (1988).

In contrast to these examples, there are fifty-five individuals listed as employees of Du Pont, and the list of universities is almost as long. It is clear that not every firm in the industry hired graduates of local universities - mainly because it was not always the case that local universities produced graduates with the skills required during this period. Although the Who's Who was published in 1928, most of the individuals who appear in it had been with the firms for many years, most of them having been hired in the previous decade or earlier.

The example of Alfred Newton Richards' work for Merck provides one example how academics played active roles in the establishment of in-house R\&D labs. Richards essentially acted as a head-hunter and recruiter when Merck set up its in-house facilities starting in 1930. Richards was professor of pharmacology and vice-president of medical affairs at the University of Pennsylvania. As Swann notes, "The University of Pennsylvania was a logical site for Merck to establish connections for biomedical research and clinical 
investigations of its drugs. Pennsylvania was a major research institution with access to extensive clinical facilities; the university was conveniently located not far from Rahway; and most important, Merck had close contact with one of the faculty whom the university community esteemed - Newton Richards" (Swann, 1988, 74-75). Richards acted as a liaison between Merck and the academic community, helping not just in recruiting but also in the organization of collaborative projects. Students and clinicians at Penn carried out the investigation and testing of methylcholine, a vasodilator eventually marketed by Merck as Mecholyl Chloride. Pharmacologists at Penn also helped develop Vinethene, an anaesthetic originally discovered by a pharmacologist at the University of California Medical School. Merck "did not feel that it would be advantageous to spend a great deal of money for the pharmacological study of vinyl ether in California. The distance was so great that a true cooperation could not be obtained."13 Instead, the work was undertaken by clinical faculty at the more geographically proximate University of Pennsylvania.

While firms with larger R\&D budgets often engaged academic consultants at more distant universities who were specialists in a specific field, younger and smaller firms appear to have been more likely to collaborate with local academics. Starting in 1925, Northwestern University chemist Arthur Tatum did routine testing a few times a year for the small Chicago firm Cook Laboratories. Tatum had no unique knowledge of the drugs he tested, and Swann notes that "Cook probably engaged Tatum simply because of his proximity to the firm" (Swann, 1988, p. 103). Selman Waksman worked part-time at nearby Cutter Laboratories while a graduate student at UC Berkeley and at Takamine Labs of New Jersey while a young assistant professor at Rutgers (Israel, 2004).

${ }^{13}$ Letter from Merck scientist R.T. Major to A.N. Richards, quoted to Swann, 1988, p. 77. 
Geographic proximity appears to matter most for (a) labs at early stages of development, or (b) relatively informal or occasional consulting contracts on general scientific matters, but not large-scale research projects requiring specialized scientific knowledge. For example, Lilly had 4 general consultants at nearby universities by 1943: an organic chemist from U Chicago $(\$ 2000 / y r)$, chemical engineer from Purdue $(\$ 600 / y r)$, biochemist from U Illinois $(\$ 600 / y r)$, organic chemist from U Indiana $(\$ 2,400 / y r)$ (Swann, 1988, p. 52). However, Lilly's large-scale collaborative research projects were undertaken with researchers at more distant universities, for example their collaboration with Banting and Best's work on synthesizing insulin at the University of Toronto, and with scientists at Harvard and the University of Rochester on the treatment of pernicious anemia in the 1920s (Swann, 1988, Chapter 5).

\section{III.2.3. Some from early university-firm interactions: Data from patents}

Some of the fruits of the early collaborations between universities and pharmaceutical firms can be found in data on firm-level patenting in the 1930s. Combining data gleaned from original patent documents with the 1930 and 1935 registries of the American Chemical Society, we have identified the affiliations of many of the inventors listed on the patents granted to the firms in our sample in 1938. Among the subset of patents for which we were able to identify at least one inventor's affiliation, approximately $13 \%$ included at least one academic inventor. (We were able to identify the inventors for 184 of the 384 patents we examined.) Among prominent pharmaceutical firms Abbott, Lilly, and Parke-Davis, $50 \%, 56 \%$, and $67 \%$ of patents granted, respectively, included academic inventors (when the inventor could be identified in the ACS directory). Other well-known firms with academic inventors include Merck ( 1 of 8 patents whose inventors could be 
identified had an academic inventor) and Sharp and Dohme (1 of 1). Some smaller firms, including Ostro Research Labs Lewis Chemical Co, Sonneborn and Sons, Zonite Products Corp., and Commercial Solvents Corp. also included academic inventors on their patents, as did Monsanto (although for only 2 of 21 patents with identifiable inventors). While this sample is not sufficiently large to derive substantial statistical power, it provides suggestive evidence of considerable academic involvement in important research-oriented tasks in some pharmaceutical firms as early as 1938.

\section{III.3. Reciprocal relationships: Historical evidence of the influence of early $20^{\text {th }}$ century firms on academic science}

In addition to the documented episodes of academic researchers' roles in nurturing the birth and growth of industrial pharmaceutical research, the historical record suggests that a number of companies were influential in shaping the evolution of university research programs. The relationships between Merck and Rutgers University and DuPont and the University of Delaware appear to be illustrative of this phenomenon.

Merck's choice of Rahway, NJ as the location for the plant it built in 1899 influenced in part by a board member who owned land in the community (Feldman and Schreuder, 1996, p. 856) - proved propitious for nearby Rutgers University. In the 1930s, Merck developed a relationship with microbiologist Selman Waksman of the College of Agriculture at Rutgers. Starting in 1939, Merck agreed to supply assistance for antibiotics developed by Waksman, who would assign all ensuing patents to Merck in exchange for a $2.5 \%$ royalty to be paid to Rutgers. In 1943 Waksman developed streptomycin, a new blockbuster antibiotic that was less toxic and more effective (particularly in treating tuberculosis) than existing alternatives. Motivated by fear of a public outcry over the 
monopolization of such an important drug, Waksman and Rutgers convinced Merck to relinquish their rights to Waksman's patents to the Rutgers Research and Endowment Fund, which licensed the patent to several competing companies. The Fund collected $\$ 12$ million in royalties from Waksman's discoveries over the next forty years. Swann quotes Waksman, whose work earned the Nobel Prize for Medicine in 1952, as suggesting that he owed more to support from Merck than from Rutgers for the discoveries (Swann, 1988). ${ }^{14}$

The University of Delaware's relationship with Du Pont proved to be similarly beneficial to that institution. Established in 1802 on the banks of the Brandywine river, in part because the location provided easy access to waterpower and an abundant supply of willow trees (from which charcoal could be produced), Du Pont was founded long before chemical research was widespread in American universities and, consequently, without regard to the availability of local academic science. Nonetheless, Du Pont played an important role in the subsequent development of scientific research at the University of Delaware through a number of significant gifts from the $\mathrm{Du}$ Pont family and other individuals associated with Du Pont. In 1924, the first physics professor was brought to Delaware with the help of Lammot Du Pont, who contributed \$2,000 for equipment and pledged an additional $\$ 600$ a year for five years, half for research equipment and half to top off the new professor's salary (Munroe, 2004, Chapter 9). The university's chemical laboratory was established between 1935 and 1937 with a \$300,000 gift from Fletcher Brown, a former Du Pont Vice President. Brown also made a donation to supplement the salary of Allan Colburn, a Du Pont engineer who became the first professor of Chemical Engineering at Delaware in April 1938. Chemical Engineering quickly became the most

\footnotetext{
${ }^{14}$ Waksman stated that, "Without the help...of an industrial organization that took over a major part of the pharmacological evaluation of the antibiotic [streptomycin] and large-scale production our contribution would have never attained its goal" (Swann, 1998, p. 90).
} 
active field of research at the university, with the possible exception of the agricultural experiment station (Munroe, 2004, Chapter 10).

\section{Data on Universities and Pharmaceutical Research Laboratories, 1920-1946}

We use the historical and mainly qualitative evidence of the preceding section to inform and complement a quantitative analysis of the role of academic science in the establishment of industrial research labs. Our analysis takes advantage of data on the number of research labs by city over several years from the publication Industrial Research Laboratories of the United States, collected by the National Research Council. In 1920 the National Research Council began to circulate surveys inquiring about firms' industrial research activities. While the term "industrial research" was interpreted broadly to include development and product improvement, the term "laboratory" was restricted to apply only to those departments of companies that had "separate and permanently established research staff and equipment," excluding "firms that indicated they only occasionally carry out research, using teams temporarily recruited for the purpose or assembled from their operating staffs" (Industrial Research Laboratories of the United States, 1956, Introduction, p. 2). Government and university laboratories were excluded, as were labs that conducted testing and analysis but no research.

These publications contain information on the characteristics of industrial research labs in nineteen years between 1920 and $1985 .{ }^{15}$ In the earliest years in which the series was published, these characteristics include the firm's address, the number of its research employees, and a brief description of its activities. In later years, the surveys list the labs'

\footnotetext{
${ }^{15}$ The years in which volumes were published are: 1920, 1927, 1931, 1933, 1938, 1940, 1946, 1948, 1950, 1956, 1960, 1965, 1970, 1975, 1977, 1979, 1982, 1983, and 1985.
} 
founding dates, number of scientific and other personnel by type (i.e.: biologists, chemists, etc.), the names of important researchers, scientific journals published by the lab, and their partners in collaborative research. ${ }^{16}$

We combine these data with (a) information on American universities drawn from the Bulletin of the Office of Higher Education (Biennial of Education) and the American Council on Education's serial publication American Universities and Colleges ${ }^{17}$ and (b) data on county-level population and manufacturing establishments drawn from the US censuses of population and US censuses of manufacturing, respectively, for the years 1920-1950. ${ }^{18}$ By including population and manufacturing data in the county-level regressions, we control for the extent to which the size, magnitude of economic activity, and, to a degree, urbanization affect the extent of industrial pharmaceutical research in US counties.

Figures 4, 5, and 6 plot the industrial research labs, universities, and manufacturing establishments, by county on maps of the United States, respectively. ${ }^{19}$ The figures suggest that manufacturing and industrial research were more concentrated (particularly in the manufacturing belt of the Northeast/Midwest) than were population and universities and colleges. Table 2 provides summary statistics from the dataset. It shows that counties with more Ph.D.-granting universities tend to have a much larger number of chemical/pharmaceutical industrial research labs per capita, in each year of the sample. We restrict ourselves to data on the number of labs per county in the years 1927, 1938, and 1946.

\footnotetext{
${ }^{16}$ Starting in 1950, the volumes also contain indices of universities that participate in collaborative research, indicating whether or not the university possesses "facilities for research in practically all fields of science", its facilities are limited to specific fields, or it has particular capabilities in certain areas.

${ }^{17}$ We thank Claudia Goldin for making the Biennial data available.

${ }^{18}$ In matching the county-level manufacturing and population data to the county-level lab data, we were careful to account for changes over time in county boundaries.

${ }^{19}$ Manufacturing and population are plotted only for those counties above the median for the country.
} 


\section{Evaluating the Role of Universities as a Determinant of Pharmaceutical Laboratory Growth}

Table 3a contains results from panel regressions in which the dependent variable is the number of pharmaceutical industrial research labs by county and year. Because our dependent variables are non-negative integers truncated at zero (i.e., count variables), we employ Negative Binomial regressions designed to account for these characteristics of the data. To facilitate the interpretation of the coefficients on the covariates as elasticities, each of these enters in logs. ${ }^{20}$ Each regression includes county population and the number of manufacturing establishments in the county to control for factors associated with county size and economic composition. Throughout the Table, we address county-specific heterogeneity by controlling for the impact of initial conditions (conditions in the county in 1927) on the number of laboratories in subsequent years of the data.

In the first four columns of Table 3a, we model the number of pharmaceutical labs in a county as a function of county population, county manufacturing establishments, the initial number of pharmaceutical labs in the county in 1927, and, depending on the column, both the 1927 count and contemporaneous count of Chemistry or Science-oriented PhDs granted by universities in the county. ${ }^{21}$ The initial number of pharmaceutical labs in the county helps control for county-level heterogeneity, but is also relevant for adjudicating competing hypotheses regarding the birth of industrial research labs. Specifically, the significance and direction of the coefficient on initial labs helps evaluate whether their growth is random or follows a pattern consistent with convergence or divergence. This variable enters positively and significantly in each of the models. That implies that counties with more

\footnotetext{
${ }^{20}$ In each case, we add 1 to the variable before taking logs.

${ }^{21}$ These variables are expressed in logs to account for heteroskedasticity.
} 
pharmaceutical labs in 1927 had faster rates of growth in labs to 1938 and 1946. Controlling for other relevant factors, this suggests that counties with a larger number of initial laboratories are more likely to experience laboratory births in the future, a pattern consistent with the divergence hypothesis. The finding is consistent with the pattern of path dependent growth evident in Feldman and Schreuder's study of the early pharmaceutical industry in the Mid-Atlantic region (1996). Divergence does not appear to be the only significant pattern in the data, however.

To investigate the hypothesis that universities exerted a significant influence on the birth of industrial research labs, we employ the number of $\mathrm{PhDs}$ awarded in a county as a proxy for the extent to which local universities engage in relevant research. ${ }^{22}$ In Columns 1 and 2, we include the number of PhDs awarded in 1927 separately from the number of $\mathrm{PhDs}$ awarded contemporaneously. In both cases, the contemporaneous number of $\mathrm{PhDs}$ is positive and significant at the $1 \%$ level. The coefficients in these columns imply that, holding observable county characteristics constant, an increase of $10 \%$ in the number of Chemistry PhDs or overall Science PhDs is associated with a 4.0\% and 3.2\% increase in the number of labs in the county, respectively. Consistent with the fact that there is a great deal of autocorrelation in the geographic distribution of $\mathrm{PhD}$ graduates, the impact of contemporaneous degrees awarded increases when the controls for initial conditions are removed in Columns 3 and 4. Although we do not report them here, the results obtained using county-level data in Table 3a are consistent with estimates we obtained using MSAlevel data. It is also worth noting that these results are not driven by those counties in which

\footnotetext{
${ }^{22}$ We also obtained data on the universities' research expenditures for certain years. While this variable comes closer to the effect we are trying to estimate, it is not available for every university in every year. As a result, we use number of $\mathrm{PhD}$ degrees awarded, which is perhaps noisier but we would argue a reasonable proxy for the research effort of the university.
} 
the largest firms (e.g., such as Abbott, Lilly, and Merck) reside. The key results in 3a are robust to the exclusion of counties that include firms whose R\&D employment falls into the top 10 percent of the distribution. The results are also robust to the exclusion of all counties in states in New England and the Mid-Atlantic area (i.e., MD, DE, PA, NJ, NY, CT, RI, $\mathrm{MA}, \mathrm{VT}, \mathrm{NH}$, and ME).

While we would like to model the growth of pharmaceutical employment in addition to the number of labs over this period, the NRC data on lab employment are less reliable. For example, employment data may reflect total firm employment rather than lab-level employment, and, for about $10 \%$ of the observations, no employment data are listed. Although these data are more noisy, we estimate the correlates of county-level R\&D workers in Table $3 \mathrm{~b}$. The pattern of divergence evident in the laboratory models remains in these models; however, the influence of lagged and contemporaneous $\mathrm{PhD}$ graduates is statistically insignificant in models that include all of the laboratories in the data (Columns 1-3). The number of PhD graduates does enter in a statistically and economically significant way, however, in certain models that include only the first laboratory listed for each firm. (As a rule, the first laboratory listed is also the headquarters laboratory for the firm.) In Columns 5, the number of contemporaneous Science PhDs enters positively and significantly at the $1 \%$ level, although the initial number of county Science PhDs is statistically insignificant. The coefficient on contemporaneous Science PhDs suggests that $10 \%$ higher Science $\mathrm{PhD}$ graduates is correlated with $90 \%$ more laboratory employment in the county. Neither 1927 nor contemporaneous Chemistry PhDs graduates enters significantly when both are included in models of county R\&D employment (in Column 4); however, when the initial number of Chemistry PhDs is omitted (in Column 6), the 
contemporaneous count is significant at the $1 \%$ level. Considering the noisiness of the lablevel counts of $R \& D$ employment, we interpret these results as suggestive of a relationship between proximate academic science and county R\&D employment, at least in the case of headquarters facilities.

Table 4 contains the results of conditional fixed-effects Negative Binomial regressions run on all years $(1927,1938$, and 1946) and including a county-level fixed effect to control for time-invariant characteristics of the county that may be associated with both the location of R\&D and academic science. The coefficients in Table 4 are thus identified by changes over time in the number of $\mathrm{PhDs}$ granted and the extent of $\mathrm{R} \& \mathrm{D}$ located in a county. They continue to exhibit a positive and significant association between academic research in Chemistry and in science more broadly (with a slightly larger effect coming from Chemistry) after controlling for unobserved heterogeneity across counties.

In this table, we also present estimates that use a distance-weighted count of $\mathrm{PhDs}$ within a 500 mile radius of the county in which the lab is located. ${ }^{23}$ These distanceweighted counts are calculated by summing up PhDs granted by all universities within 500 miles, weighted by the distance between the county and the lab. That is, we calculate $P h D_{-} w t_{\mathrm{it}}=\sum_{j} \frac{P H D s_{\mathrm{j}}}{1+\mathrm{d}_{\mathrm{ij}}}$,

where $\mathrm{PhD} \_$wt for firm $i$ is the number of $\mathrm{PhDs}$ nearby, weighted by the distance between firm $i$ and university $j$. Nearby $\mathrm{PhDs}$ would get a very high weight (very low inverse weight), whereas PhD 500 miles away make almost no contribution to the count. We calculate these variables and estimate the relationship between them and the R\&D variables

\footnotetext{
${ }^{23}$ We thank Toby Stuart for suggesting a distance-weighted measure. We modeled our PhD count on the "IPO concentration" measure found in Stuart and Sorensen (2003).
} 
because of concerns about the arbitrary nature of county boundaries. The fact that M.I.T., located in Middlesex county, MA, is a stone's throw from Boston and Suffolk county means that when we use county boundaries to define the radius within which we expect spillovers to take place, we will sometimes miss important potential relationships at the boundaries of counties. We use the distance-weighted counts as a robustness check, and find that similar results are obtained whether we use county boundaries or a continuous distance-weighted measure to define the location of "nearby" academic science.

It should be noted here that the data on research labs may not be exhaustive of all the labs in existence for the early years during which it was collected. The Appendix to this paper reproduces an excerpt from the introduction to the 1927 edition of the series. It explains that members of the main scientific and engineering associations were consulted in order to establish a list of firms known to have in-house research labs, and the published information is based on surveys were sent to these firms. It is important to determine what effect this sampling bias might have on the results, that is, whether the correlation between labs and universities per county could be an artifact of the way the sample was constructed. If, for example, regional branches of scientific and engineering associations tended to be located near universities, they may have had more information about research labs in the surrounding community. To guard against this possibility, we ran regressions that include a dummy variable equal to 1 if there was a branch of the American Chemical Society (ACS) located in county $i$ in year $t^{24}$ In the event that a bias is introduced by the tendency of ACS branches to locate near universities, this dummy will correct for that bias. Column 5 of Table 3a shows that the coefficient in the on the number of chemistry PhDs is slightly

\footnotetext{
${ }^{24}$ These data were obtained from the Directory of Members of the American Chemical Society. Directories from 1924, 1930, and 1947 listed the locations of branch headquarters and the year in which they were chartered.
} 
reduced, but remains significant at the $5 \%$ level. Similar results are obtained for the other specifications if the ACS branch dummy is included.

\section{Mechanisms of university-industry interaction: Collaboration}

We look more closely at the role played by proximity to academic science in Table 5 , in which the firm's decision to collaborate with academic scientists is modeled as a function of the extent of research undertaken at nearby universities. The number of $\mathrm{PhDs}$ in science or chemistry awarded by local universities is positively and significantly associated with the propensity of pharmaceutical firms to engage in collaborative research with universities. Firms with larger numbers of researchers are significantly more likely to engage in cooperative research, and older firms are slightly more likely to collaborate with academic scientists. ${ }^{25}$ We also estimated specifications including the manufacturing or population intensities of the county, and these variables were insignificantly associated with the probability of collaboration. To test the hypothesis that collaboration with local academic scientists was more important for firms at different stages of the life cycle, we include interaction effects of local chemistry research with age and size in columns 4 and 5 . The coefficient on the interaction of age and nearby PhDs in chemistry is insignificant at the $5 \%$ level. This is slightly surprising, considering our expectation that younger firms might be relatively lacking in internal research capabilities and therefore more likely to benefit from collaboration with local scientists. The effect of local academic chemistry research does not appear to vary according to firm size, however, since the interaction of firm size and chemistry PhDs is not significant at the 5\% level.

\footnotetext{
${ }^{25}$ When the age variable is included, the number of observations falls because age is only observed in the 1946 sample.
} 


\section{Statistical evidence on the influence of private industry on university programs}

Our qualitative evidence suggests that the research needs of large firms played a role in the evolution of at least a few universities. Our quantitative analysis offers mixed support for this proposition. Table 6 reports the results of logit regressions at the level of the university that examine the determinants of the adoption of a chemical engineering program for the first time between 1937 and 1947. We use the full sample of universities and colleges drawn from the publication American Colleges and Universities, excluding religious seminaries, teacher's colleges, and junior colleges. Data on engineering programs in American universities are drawn from the United States Office of Education's Bulletins. ${ }^{26}$ The dependent variable takes on the value 1 if the university established a department of chemical engineering for the first time between 1937 and 1947, and 0 if not. Universities that had already established programs by 1937 are omitted from the analysis. This variable is regressed on a measure of pharmaceutical research in industry in the county in 1938 , the population and number of manufacturing establishments in the county in 1940 and 1939 respectively, and the growth of population, manufacturing, and industrial research in pharmaceuticals during the period. ${ }^{27}$ The results show that universities located in counties that were centers of research in the pharmaceutical industries in 1938 were significantly more likely to establish a department of chemical engineering between that year and 1947 , even after controlling for the growth of the industry during that period. This appears to be evidence of a feedback effect in which the presence nearby firms influenced the programs offered by universities. Such effects were not evident, however, when we looked at

\footnotetext{
26 The Bulletins, part of the series "Accredited Higher Institutions" were published in 1938 and 1948.

${ }^{27}$ For universities in cities that fall in multiple counties, we use the average of these variables.
} 
universities that began granting Ph.D.s in Chemistry during this period. We were also unable to find evidence of "anchor" effects in the data (Agrawal and Cockburn, 2003; Feldman, 2003), in which especially large firms had a particularly large impact on the growth of local university programs in sciences or chemistry.

\section{Instrumental Variables Estimates}

Preceding sections of this paper document a statistically significant, positive relationship between the number of pharmaceutical industrial research laboratories in a county and university research in a county, after controlling for other variables likely to influence the location decision of R\&D labs and including a county-specific fixed effect. These results imply that growth over time in the amount of university research (as measured by the number of PhDs granted) in a county was associated with growth over time in pharmaceutical R\&D in a county. However, because university research is also likely to have been stimulated by nearby industrial research (through consulting contracts, joint research projects, demand for graduates, etc.), we cannot necessarily infer a causal interpretation from this relationship. Indeed, the stories of Chemical Engineering at the University of Delaware and the streptomycin royalties at Rutgers, together with the results presented in Table 6, illustrate the possibility of "feedback effects" from firms to universities during this period. As Geiger observes, "but if the universities were dedicated to science, broadly speaking, by the beginning of the twentieth century, it was not yet evident that science was or ought to be beholden to universities. Scientific investigation was undertaken in government bureaus and in semi-independent laboratories... [E]ven by 1920 
the research universities could not be assured of being the primary locus of basic research" (Geiger, 1986).

Panel estimates of the relationship between university and industrial research are likely to be characterized by simultaneity - research universities attracted industrial laboratories, and the research conducted in these laboratories affected nearby academic departments. In this section, we use instrumental variables to correct for this simultaneity bias. The instruments are the amount of money obtained as the proceeds of the sale of land and scrip granted to the state under the Morrill Act of 1862, and a dummy variable equal to 1 if a university in the county was founded before 1800 .

The Morrill Act established the "land-grant" colleges by giving the states public lands that could be sold and to finance the colleges. A state received 30,000 acres for each member of its congressional delegation, and since the smallest states had at least two senators and one representative, the minimum land grant consisted of 90,000 acres. The Hatch Act of 1887 provided funding for agricultural experiment stations, and a second Morrill Act in 1890 extended the land grant provisions to southern states.

While the amount of land granted under the Morrill Act was proportional to the size of the state, the sale price per acre obtained by states varied considerably, and for somewhat aleatory reasons. Nevins (1963) writes that:

"A great deal of obscurity yet surrounds the precise disposition made by some states of their share of the Morrill grant... Many university historians tend to pass over the disposition of the grants hastily...partly because the story has occasional elements of folly and rascality that make it embarrassing. A number of states let the land scrip slip through their fingers; fingers loosed by negligent officers, pried apart by speculators, or even greased by corruptionists" (p. 29).

Rhode Island was granted 120,000 acres, and asked Rev. Horace T. Love (president of Brown University) to select the land for sale. He went west in the summer of 1863 , and 
came back "to report that the task was impossibly heavy, for it involved choosing lands, paying taxes, negotiating sales, and defending titles" and a committee of five was appointed by Love to take charge. The committee then sold the land to Love in 1865 for $\$ 50,000$ (the lowest amount received by any state, and the third lowest per acre), accepting payment over five years with no interest. Nevins is "not astonished to learn that the sale aroused much criticism." In Pennsylvania, "Heavy pressure had come from an unholy partnership of land speculators, anxious to obtain a bargain, and officers of the state college, anxious to get funds for a new start" Other states in which the sale of Morrill lands was bungled include New Jersey, New Hampshire, and Connecticut (all quotes from Nevins, 1963, p. 29-31).

In contrast, states like New York managed to turn the grants into more significant endowments. Faced with a glut of land scrip and depressed land prices following the Act, Ezra Cornell purchased New York's scrip and held it until prices rose. When Cornell returned the land and profits to the university in 1905 , the value had risen almost seven-fold, to $\$ 5,460,038$. California, Illinois, Iowa, Michigan, Minnesota, and Nebraska, also obtained higher prices per acre for their scrip. The appendix lists the acreage granted and amount obtained at sale, by land grant institution. ${ }^{28}$

The price per acre obtained for Morrill Act land grants had a long-run impact on university finances. The states that obtained the most for their scrip are the ones that are even today home to the better-funded public universities. However, because the price per acre obtained by the states varied substantially for reasons unrelated to the state's attractiveness to industrial research labs seventy years hence, it constitutes a valid instrument.

${ }^{28}$ These data come from the U.S. Office of Education's Biennial of Higher Education, 1928. 
The instruments vary by county - they equal zero for all counties not containing a public university. There may be some concern that states placed universities in counties with heavy manufacturing concentration, and that for this reason the land grant instrument is correlated with the errors. While it is true that states had a mandate to serve agricultural and manufacturing interests through public universities, we feel that this concern is misplaced because any influence the location of manufacturing in the mid- to late-nineteenth century may have had on the location of public universities is controlled for through the inclusion in the regression of the number of manufacturing establishments in the county.

Table 7a presents results of a two-stage least squares (2SLS) model in which the endogenous variable is $\log$ of the number of PhDs granted in a county, and the instruments are the original sale price received by states for land and scrip obtained through the Morrill Act and the dummy for universities founded before 1800. Two sets of regressions results are included, one with the log of the number of labs on the left hand side, and another with the $\log$ of R\&D employment. We control for manufacturing, population, and year and region fixed effects (county or state fixed effects could not be included due to collinearity with the instruments). The relationship between university research in a county and pharmaceutical R\&D is positive and significant at the 5\% level after instrumenting, whether research is proxied by Chemistry PhDs or Science PhDs. The first-stage F-statistic (from the regression of the endogenous variable on the instruments) is 64.4 for chemistry and 76.3 for science. These values are well above the "rule-of-thumb" F-statistic of 10 proposed by Staiger and Stock (1997) as a test for weak instruments.

To be consistent with the rest of the estimates in the paper, which use the Negative Binomial model to account for the discrete, non-negative nature of the dependent variable, 
Table $7 \mathrm{~b}$ presents non-linear two-stage least squares estimates obtained using the Generalized Method of Moments (GMM). ${ }^{29}$ The GMM estimates remain positive and significant at the 5\% level when the left-hand-side variable is the number of labs. However, when we estimate the causal effect of local academic science on R\&D employment in the county, the effect is not significant. We also tried estimating the IV models with distanceweighted $\mathrm{PhDs}$ on the right-hand-side, and obtained similar results - a positive, significant effect of science or chemistry PhDs when the dependent variable is the number of labs, but a positive, insignificant effect when the dependent variable is lab employment. The instruments are also equally valid when we use distance-weighted PhDs.

How do the effects compare to the un-instrumented effects displayed in Table 4? In the fixed-effects Poisson estimates, the elasticity of the number of labs with respect to the number of Chemistry $\mathrm{PhDs}$ is 0.450 , implying that a $10 \%$ increase in the number of Chemistry PhDs awarded in a county is associated with a $4.5 \%$ increase in the number of pharmaceutical research laboratories nearby, controlling for county-specific fixed effects. After instrumenting, the elasticity of labs with respect to Chemistry PhDs found in the GMM estimates in Table $7 \mathrm{~b}$ is 0.325 . The elasticity with respect to science $\mathrm{PhDs}$ sees a similar reduction from 0.342 to 0.224 .

\section{Discussion}

The 1920s, 30s, and 40s saw the diffusion of an organizational innovation in the form of the in-house R\&D laboratory in the United States. Also during this period, the modern American research university developed and collaborative linkages emerged

${ }^{29}$ See Mullahy (1997) for an example of a GMM model for count data with endogenous regressors. 
between industrial and academic researchers. We argue that universities played an important role in the emergence of industrial research situated within the boundaries of the firm, and we present evidence that R\&D labs located near universities benefited from increased access to academic scientists and graduates. The results described in this paper characterize the relationship between universities and the pharmaceutical industry between 1927 and 1946. They demonstrate that industrial and academic research were co-located, and that proximity to university research was associated with a greater likelihood that firms adopt industrial research facilities and collaborate with academic scientists.

Our qualitative and quantitative analyses provide evidence consistent with the possibility of feedback effects, according to which university programs were affected by the presence of pharmaceutical industry activity. Specifically, our empirical results suggest that universities located near larger numbers of industrial research labs in chemistry and pharmaceuticals as of 1938 were more likely to establish new programs of chemical engineering by 1946.

In an attempt to identify the causal effect of academic science on the growth of industrial research, we employ an instrumental variables approach to correct for simultaneity bias in our estimates of the impact of university research on the birth of industrial research laboratories. In sum, our analyses suggest that while the presence of industrial facilities helped shape the direction of university research programs, there was a significant, positive, and causal effect running from university research to the growth of industrial research laboratories in the first half of the twentieth century in the United States. 


\section{References}

Acs, Z., D. Audretsch, and M. Feldman (1992) "Real Effects of Academic Research: Comment," American Economic Review, 82(1), 363-367.

Adams, J. D. (2002) "Comparative Localization of Academic and Industrial Spillovers," Journal of Economic Geography, 2(3): 253-278.

Agrawal, A. and I. Cockburn (2003) "The Anchor Tenant Hypothesis: Exploring the Role of Large, Local, R\&D-Intensive Firms in Regional Innovation Systems," International Journal of Industrial Organization, 21: 1227-1253.

American Chemical Society $(1924,1930,1947)$ Directory of members - American Chemical Society. Washington, D.C., American Chemical Society.

Arora, A., A. Fosfuri, and A. Gambardella (2001) Markets for Technology: The Economics of Innovation and Corporate Strategy. Cambridge, MA: The MIT Press.

Arora, A., A. Fosfuri, and A. Gambardella (2003) "The Division of Inventive Labor: Functioning and Policy Implications," working paper, presented at the NBER, Zvi Griliches Memorial Conference in Paris, FR.

Council on Competitiveness (1996), Endless Frontiers, Limited Resources: U.S. R\&D Policy for Competitiveness, Washington, D.C., Council on Competitiveness.

Fisk, C. (1998) "Removing the 'Fuel of Interest' from the 'Fire of Genius': Law and the Employee-Inventor, 1830-1930," University of Chicago Law Review, 65, 1127.

Feldman, M. P. (2003) "The Locational Dynamics of the US Biotech Industry: Knowledge Externalities and the Anchor Hypothesis," Industry and Innovation, 10: $311-328$.

Feldman, M. and Y. Schreuder (1996) "Initial advantage: The origins of geographic concentration of the pharmaceutical industry in the Mid-Atlantic region," Industrial and Corporate Change, Vol. 5, 839-862.

Furman, J. (2003) "Location and Organizing Strategy? Exploring the Influence of Location on Organization of Pharmaceutical Research," in Joel A.C. Baum and Olav Sorenson (ed.), Advances in Strategic Management, 49-88.

Galambos, L. with J. E. Sewell (1995) Networks of Innovation: Vaccine Development at Merck, Sharp \& Dohme, and Mulford, 1985-1995. Cambridge, UK: Cambridge University Press.

Gans, J. and S. Stern (2003) "The Product Market and the Market for Ideas: Commercialization Strategies for Technology Entrepreneurs," Research Policy, 32(2), pp. 333-350.

Geiger, R. L., (1986) To Advance Knowledge: The Growth of American Research Universities, 1900-1940. New York, NY: Oxford University Press.

Goldin, C. and L. F. Katz (1999) "The Shaping of Higher Education: The Formative Years in the United States, 1890 to 1940," Journal of Economic Perspectives, Winter 1999, p. 37-62 
Hounshell, D. A. and J. K. Smith, Jr. (1988), Science and Corporate Strategy: DuPont $R \& D, 1902-1980$. New York: Cambridge University Press.

Israel, P. (2004) "Waksman - Biography," http://www.scc.rutgers.edu/njh/SciANDTech/Waksman/biog.htm (accessed July 16, 2004).

Jaffe, A. "Real Effects of Academic Research" (1989), American Economic Review, 79 (5), p. 957-70.

Jaffe, A., M. Trajtenberg and R. Henderson (1993) "Geographic Localization of Knowledge Spillovers as Evidenced by Patent Citations," The Quarterly Journal of Economics, 108 (3), p 577-98.

Journal of the American Medical Association (1915) "Special Report of the Work of the Council on Pharmacy and Chemistry," 65, p. 69.

Lamoreaux, N. and K. Sokoloff (1996) "Long-term change in the organization of inventive activity," Proceedings of the National Academy of Sciences, 93, 1268612692.

Lamoreaux, N. and K. Sokoloff (2002) "Intermediaries in the U.S. Market for Technology, 1870-1920”, NBER Working Paper no.9017

Lewis, S. (1925) Arrowsmith. New York, NY: Grosset and Dunlap.

Liebenau, J., Higby, G. J., and E. C. Stroud (1988) Pill Peddlers: Essays on the History of the Pharmaceutical Industry. Madison, WI: American Institute of the History of Pharmacy.

Mahoney, T. (1959) The Merchants of Life. New York, NY: Harper Brothers.

Mann, C. C. and M. L. Plummer (1991) The Aspirin Wars. New York, NY: Knopf.

Mowery, D. and N. Rosenberg (1998) Paths of Innovation: Technological Change in 20th-Century America, Cambridge; New York: Cambridge University Press.

Mowery, D. (1983) "Industrial Research and Firm Size, Survival, and Growth in American Manufacturing, 1921-46: An Assessment”. Journal of Economic History, 43 (4), p. 953-980.

Mowery, D. (1990) "The Development of Industrial Research in U.S. Manufacturing," American Economic Review, 80(2), p. 345-349

Mowery, D., R. Nelson, B. Sampat, and A. Ziedonis (2003) "Ivory Tower" and Industrial Innovation: University-Industry Technology Transfer Before and After the Bayh-Dole Act in the United States, Manuscript

Mullahy, J. (1997) "Instrumental-Variable Estimation of Count Data Models: Applications to Models of Cigarette Smoking Behavior," Review of Economics and Statistics, 79, 586-593.

Munroe, J. (2004) "The University of Delaware: A History," http://www.udel.edu/PR/munroe/ (accessed, July 1-7, 2004) 
Murmann, J. P. (2003) Knowledge and Competitive Advantage: The Coevolution of Firms, Technology, and National Institutions. New York, NY: Cambridge University Press.

National Research Council (1921) Bulletin 16, "Research Laboratories in Industrial Establishments of the United States, Including Consulting Research Laboratories", Washington, D.C.: National Research Council.

National Research Council (1927-85) "Industrial Research Laboratories of the United States", Washington, D.C.: National Research Council.

Nelson, R. and N. Rosenberg (1994) "American Universities and Technical Advance in Industry," Research Policy, 23, 323-348.

Nelson, R. R. and G. Wright (1992) "The Rise and Fall of American Technological Leadership," Journal of Economic Literature, 30(4): 1931-1964.

Nevins, A. (1962) The State Universities and Democracy, Urbana: University of Illinois Press.

Parascandola, J. (1985) "Industrial Research Comes of Age: The American Pharmaceutical Industry, 1920-1940," Pharmacy in History, 27(1), pp. 12-21.

Peretto, P. (1998). "Technological Change, Market Rivalry, and the Evolution of the Capitalist Engine of Growth", Journal of Economic Growth, 3 (1), p. 53-80.

Rosenberg, N. (2000) “America's University/Industry Interfaces, 1945-2000”, Manuscript, Stanford University.

Staiger, D. and Stock, J. (1997) "Instrumental Variables Regression with Weak Instruments," Econometrica, 65(3), May 1997, 557-586.

Stuart, T. and O. Sorensen (2003), "Liquidity Events and the Geographic Distribution of Entrepreneurial Activity”, Administrative Science Quarterly, 48 (2003): 175-201

Swann, J.P. (1988) Academic Scientists and the Pharmaceutical Industry, Baltimore: Johns Hopkins University press.

Swann, J.P. (1990) "Universities, Industry, and the Rise of Biomedical Collaboration in America," in Liebenau et al. (ed.) Pill Peddlers: Essays on the History of the Pharmaceutical Industry. Madison, WI: American Institute of the History of Pharmacy, pp. 73-90.

Teece, D. (1988) "Technological Change and the Nature of the Firm," in G. Dosi, C. Freeman, R. Nelson, G. Silverberg, and L. Soete (eds.), Technical Change and Economic Theory. London: Pinter, 256-281.

Haynes, W. (1928) Who's Who in Chemistry. New Haven, CT: Haynes \& George Co.

Zucker, L., M. Brewer, and M. Darby (1998) "Intellectual Capital and the Birth of U.S. Biotechnology Enterprises," American Economic Review, vol. 88, no. 1, pp. 290-306 
Table 1: Pharmaceutical Research Labs and Academic Collaborators, 1938

\begin{tabular}{|c|c|c|}
\hline Laboratory & Location & University \\
\hline Bauer and Black & Chicago, IL & Northwestern, U Chicago, U Michigan \\
\hline $\begin{array}{l}\text { Breon and Company, Inc., } \\
\text { George A. }\end{array}$ & Kansas City, MO & U Nebraska, U Kansas, U Cincinnati \\
\hline Bristol-Meyers Company & Hillside, NJ & $\begin{array}{l}\text { Carnegie Institute Technology, Rutgers, } \\
\text { Stanford }\end{array}$ \\
\hline $\begin{array}{l}\text { Carbide and Carbon } \\
\text { Chemicals Corporation }\end{array}$ & $\begin{array}{l}\text { South Charleston, } \\
\text { WV }\end{array}$ & Mellon Institute Industrial Research \\
\hline $\begin{array}{l}\text { Commercial Solvents } \\
\text { Corporation }\end{array}$ & Terre Haute, IN & Purdue University \\
\hline Drackett Company & Cincinnati, $\mathrm{OH}$ & Ohio State University \\
\hline Emerson Drug Company & Baltimore, MD & U Maryland; U Illinois; Yale \\
\hline Endo Products, Inc. & New York, NY & NYU \\
\hline Harshaw Chemical Company & Cleveland, $\mathrm{OH}$ & Western Reserve University \\
\hline $\begin{array}{l}\text { Hynson, Westcott, and } \\
\text { Dunning, Inc. }\end{array}$ & Baltimore, MD & John Hopkins University, U Maryland \\
\hline Jergens Company, Andrew & Cincinnati, $\mathrm{OH}$ & University Cincinnati \\
\hline Kessler Chemical Corporation & Philadelphia, PA & $\begin{array}{l}\text { Philadelphia College Pharmacy and } \\
\text { Science }\end{array}$ \\
\hline $\begin{array}{l}\text { LaMotte Chemical Products } \\
\text { Company }\end{array}$ & Baltimore, MD & Western Reserve University \\
\hline Merck and Company, Inc & Rahway, NJ & $\begin{array}{l}\text { U California; John Hopkins; U } \\
\text { Pennsylvania; Princeton; NYU; Tulane; } \\
\text { MIT; Philadelphia College Pharmacy; } \\
\text { Cornell, Rutgers }\end{array}$ \\
\hline $\begin{array}{l}\text { Monsanto Chemical } \\
\text { Corporation }\end{array}$ & $\begin{array}{l}\text { St. Louis, MO; } \\
\text { Dayton, } \mathrm{OH}\end{array}$ & $\begin{array}{l}\text { U Cincinnati, U Illinois, Michigan U, U } \\
\text { Nevada, U Wisconsin, and Princeton }\end{array}$ \\
\hline $\begin{array}{l}\text { National Oil Products } \\
\text { Company, Inc. }\end{array}$ & Harrison, NJ & $\begin{array}{l}\text { Harvard Medical School; U Iowa; } \\
\text { Lehigh; Columbia }\end{array}$ \\
\hline Sharp and Dohme, Inc & $\begin{array}{l}\text { Glenoden, PA and } \\
\text { Baltimore, MD }\end{array}$ & $\begin{array}{l}\text { U Pennsylvania, Bryn Mawr College, } \\
\text { Johns Hopkins Hospital, Philadelphia } \\
\text { College Pharmacy and Science; U } \\
\text { California, Yale, Northwestern, } \\
\text { Rochester }\end{array}$ \\
\hline $\begin{array}{l}\text { U.S. Industrial Alcohol } \\
\text { Company }\end{array}$ & $\begin{array}{l}\text { Stamford, CT and } \\
\text { Baltimore, MD }\end{array}$ & $\begin{array}{l}\text { Kalamazoo College, Stanford, Temple, U } \\
\text { Connecticut, U Chicago, U Detroit, U } \\
\text { Michigan, U Tennessee }\end{array}$ \\
\hline
\end{tabular}

Source: Industrial Research Laboratories of the United States, 1938 
Table 2a: Descriptive Statistics

\begin{tabular}{|c|c|c|c|c|c|}
\hline & Obs & Mean & Std. Dev. & Min & Max \\
\hline Year & 9942 & 37.02 & 7.79 & 27 & 46.00 \\
\hline \multicolumn{6}{|l|}{ County-Level data } \\
\hline $\begin{array}{l}\text { County Population } \\
\text { (in hundreds of thousands) }\end{array}$ & 9304 & 0.04 & 0.15 & 0.000042 & 4.29 \\
\hline $\begin{array}{l}\text { County Manufacturing Establishments } \\
\text { (in hundreds) }\end{array}$ & 9304 & 0.72 & 5.12 & 0 & 263.28 \\
\hline Pharma laboratories & 9304 & 0.07 & 0.60 & 0 & 28.00 \\
\hline R\&D personnel & 9304 & 2.20 & 33.86 & 0 & 1712.00 \\
\hline Patents & 9304 & 0.13 & 4.02 & 0 & 236.00 \\
\hline $\begin{array}{l}\text { Cooperative arrangements with } \\
\text { universities }\end{array}$ & 9304 & 0.02 & 0.43 & 0 & 28.00 \\
\hline Count of Universities & 9304 & 0.04 & 0.28 & 0 & 6.00 \\
\hline $\begin{array}{l}\text { PhDs granted in Science } \\
\text { (continuous distance measure) }\end{array}$ & 9318 & 1.58 & 2.33 & 0 & 40.08 \\
\hline $\begin{array}{l}\text { PhDs granted in Chemistry (continuous } \\
\text { distance measure) }\end{array}$ & 9318 & 0.58 & 0.86 & 0 & 17.57 \\
\hline PhDs granted in Science in County & 9304 & 0.59 & 6.33 & 0 & 146.91 \\
\hline $\mathrm{PhDs}$ granted in Chemistry in County & 9304 & 0.21 & 2.20 & 0 & 44.45 \\
\hline \multicolumn{6}{|l|}{ Firm-Level data } \\
\hline R\&D personnel & 631 & 28.10 & 66.27 & 0 & 825.00 \\
\hline $\begin{array}{l}\text { Year firm founded } \\
\text { (only available for } 1946 \text { data) }\end{array}$ & 39 & 1886.03 & 31.31 & 1828 & 1924.00 \\
\hline $\begin{array}{l}\text { Firm Age } \\
\text { (only available for } 1946 \text { data) }\end{array}$ & 631 & 10.68 & 19.13 & 0 & 118.00 \\
\hline Patents received & 625 & 1.51 & 9.88 & 0 & 118.00 \\
\hline $\begin{array}{l}\text { Cooperative Agreement with University } \\
\text { (not available for } 1927 \text { data) }\end{array}$ & 392 & 0.54 & 0.50 & 0 & 1.00 \\
\hline \multicolumn{6}{|l|}{ University-Level data } \\
\hline Total PhDs granted & 342 & 16.97 & 29.23 & 0 & 171.55 \\
\hline $\mathrm{PhDs}$ granted in Science & 342 & 12.58 & 19.92 & 0 & 105.91 \\
\hline PhDs granted in Chemistry & 342 & 4.60 & 7.32 & 0 & 43.45 \\
\hline
\end{tabular}

Table 2b: Pharmaceutical labs per 100,000 population
Obs
Std. Dev.
Mean

Counties without a $\mathrm{PhD}$-granting university

$\begin{array}{llll}1927 & 3048 & 0.066 & 0.383 \\ 1938 & 3015 & 0.033 & 0.423 \\ 1946 & 2997 & 0.054 & 0.672\end{array}$

Counties with a PhD-granting university

\begin{tabular}{lccc}
\hline 1927 & 59 & 0.746 & 1.615 \\
1938 & 84 & 0.762 & 1.986 \\
1946 & 101 & 1.040 & 1.969
\end{tabular}

Counties with a university granting PhDs in Chemistry

$\begin{array}{llll}1927 & 48 & 0.729 & 1.647 \\ 1938 & 73 & 0.836 & 2.095 \\ 1946 & 90 & 1.056 & 1.928\end{array}$


Table 3a: Location of pharmaceutical research, 1938-1946

Negative Binomial regressions, controlling for initial conditions

\begin{tabular}{|c|c|c|c|c|c|}
\hline & (1) & (2) & (3) & (4) & (5) \\
\hline Chemistry PhDs in county ${ }^{\dagger}$ & $\begin{array}{c}0.401 \\
(0.122)^{* * *}\end{array}$ & & & $\begin{array}{l}0.555 \\
(0.156)^{* * *}\end{array}$ & $\begin{array}{l}0.310 \\
(0.123)^{* *}\end{array}$ \\
\hline 1927 Chemistry PhDs in county $^{\dagger}$ & $\begin{array}{c}0.227 \\
(0.261)\end{array}$ & & & & $\begin{array}{c}0.318 \\
(0.219)\end{array}$ \\
\hline Science PhDs in county ${ }^{\dagger}$ & & $\begin{array}{l}0.318 \\
(0.096)^{* * *}\end{array}$ & $\begin{array}{l}0.416 \\
(0.121)^{* * *}\end{array}$ & & \\
\hline 1927 Science PhDs in county ${ }^{\dagger}$ & & $\begin{array}{c}0.132 \\
(0.153)\end{array}$ & & & \\
\hline 1927 Pharma Labs in county $^{\dagger}$ & $\begin{array}{l}2.307 \\
(0.176)^{* * *}\end{array}$ & $\begin{array}{l}2.312 \\
(0.178)^{* * *}\end{array}$ & $\begin{array}{l}2.327 \\
(0.181)^{* * *}\end{array}$ & $\begin{array}{l}2.327 \\
(0.182)^{* * *}\end{array}$ & $\begin{array}{c}2.177 \\
(0.160)^{* * *}\end{array}$ \\
\hline Population $^{\dagger}$ & $\begin{array}{l}-2.273 \\
(0.578)^{* * *}\end{array}$ & $\begin{array}{l}-2.281 \\
(0.573)^{* * *}\end{array}$ & $\begin{array}{l}-2.329 \\
(0.574)^{* * *}\end{array}$ & $\begin{array}{l}-2.321 \\
(0.577)^{* * *}\end{array}$ & $\begin{array}{l}-2.458 \\
(0.548)^{* * *}\end{array}$ \\
\hline Manufacturing $^{\dagger}$ & $\begin{array}{l}0.804 \\
(0.077)^{* * *}\end{array}$ & $\begin{array}{l}0.803 \\
(0.077)^{* * *}\end{array}$ & $\begin{array}{l}0.809 \\
(0.076)^{* * *}\end{array}$ & $\begin{array}{l}0.807 \\
(0.077)^{* * *}\end{array}$ & $\begin{array}{c}0.788 \\
(0.074)^{* * *}\end{array}$ \\
\hline ACS section & & & & & $\begin{array}{c}0.625 \\
(0.205)^{* * *}\end{array}$ \\
\hline Year $=1938$ & $\begin{array}{l}-0.947 \\
(0.169)^{* * *}\end{array}$ & $\begin{array}{l}-0.949 \\
(0.167)^{* * *}\end{array}$ & $\begin{array}{l}-0.941 \\
(0.166)^{* * *}\end{array}$ & $\begin{array}{l}-0.935 \\
(0.167)^{* * * *}\end{array}$ & $\begin{array}{l}-0.918 \\
(0.157)^{* * *}\end{array}$ \\
\hline Constant & $\begin{array}{l}-6.121 \\
(0.297)^{* * *}\end{array}$ & $\begin{array}{l}-6.122 \\
(0.295)^{* * *}\end{array}$ & $\begin{array}{l}-6.152 \\
(0.292)^{* * *}\end{array}$ & $\begin{array}{l}-6.142 \\
(0.294)^{* * *}\end{array}$ & $\begin{array}{l}-6.125 \\
(0.264)^{* * *}\end{array}$ \\
\hline Observations & 6197 & 6197 & 6197 & 6197 & 6197 \\
\hline $\begin{array}{l}\text { Log Likelihood } \\
{ }^{\dagger} \text { in logs }\end{array}$ & -833.44 & -834.48 & -835.06 & -834.38 & -831.95 \\
\hline
\end{tabular}


Table 3b: Location of $R \& D$, dependent variable = laboratory employment in county $i$ in year $t$
(1)
(2)
(3)
(4)
(5)
(6)

\begin{tabular}{|c|c|c|c|c|c|c|}
\hline \multirow[b]{2}{*}{ Chemistry PhDs in county ${ }^{\dagger}$} & \multicolumn{3}{|c|}{ Using all labs } & \multicolumn{3}{|c|}{ Using only first lab listed } \\
\hline & $\begin{array}{l}-0.578 \\
(0.505)\end{array}$ & & $\begin{array}{c}0.077 \\
(0.214)\end{array}$ & $\begin{array}{c}0.930 \\
(0.590)\end{array}$ & & $\begin{array}{l}1.302 \\
(0.406)^{* * *}\end{array}$ \\
\hline 1927 Chemistry PhDs in county $^{\dagger}$ & $\begin{array}{c}1.005 \\
(0.683)\end{array}$ & & & $\begin{array}{c}0.630 \\
(0.543)\end{array}$ & & \\
\hline Science PhDs in county ${ }^{\dagger}$ & & $\begin{array}{l}-0.087 \\
(0.296)\end{array}$ & & & $\begin{array}{l}0.919 \\
(0.324)^{* * *}\end{array}$ & \\
\hline 1927 Science PhDs in county ${ }^{\dagger}$ & & $\begin{array}{c}0.278 \\
(0.380)\end{array}$ & & & $\begin{array}{l}-0.090 \\
(0.298)\end{array}$ & \\
\hline 1927 R\&D Workers in county ${ }^{\dagger}$ & $\begin{array}{l}1.117 \\
(0.159)^{* * *}\end{array}$ & $\begin{array}{l}1.114 \\
(0.158)^{* * *}\end{array}$ & $\begin{array}{l}1.117 \\
(0.155)^{* * *}\end{array}$ & $\begin{array}{l}1.009 \\
(0.252)^{* * *}\end{array}$ & $\begin{array}{l}1.032 \\
(0.249)^{* * *}\end{array}$ & $\begin{array}{l}1.023 \\
(0.247)^{* * *}\end{array}$ \\
\hline Population $^{\dagger}$ & $\begin{array}{c}0.257 \\
(2.699)\end{array}$ & $\begin{array}{c}0.211 \\
(2.711)\end{array}$ & $\begin{array}{c}0.210 \\
(2.722)\end{array}$ & $\begin{array}{l}-2.274 \\
(2.030)\end{array}$ & $\begin{array}{l}-2.324 \\
(2.027)\end{array}$ & $\begin{array}{l}-2.300 \\
(2.023)\end{array}$ \\
\hline Manufacturing $^{\dagger}$ & $\begin{array}{l}1.116 \\
(0.206)^{* * *}\end{array}$ & $\begin{array}{l}1.118 \\
(0.208)^{* * *}\end{array}$ & $\begin{array}{l}1.125 \\
(0.205)^{* * *}\end{array}$ & $\begin{array}{l}1.615 \\
(0.213)^{* * *}\end{array}$ & $\begin{array}{l}1.620 \\
(0.212)^{* * *}\end{array}$ & $\begin{array}{l}1.619 \\
(0.211)^{* * *}\end{array}$ \\
\hline Year $=1938$ & $\begin{array}{l}-3.782 \\
(0.449)^{* * *}\end{array}$ & $\begin{array}{l}-3.772 \\
(0.447)^{* * *}\end{array}$ & $\begin{array}{l}-3.771 \\
(0.446)^{* * *}\end{array}$ & $\begin{array}{l}-1.848 \\
(0.483)^{* * *}\end{array}$ & $\begin{array}{l}-1.847 \\
(0.483)^{* * *}\end{array}$ & $\begin{array}{l}-1.845 \\
(0.482)^{* * *}\end{array}$ \\
\hline Constant & $\begin{array}{l}-2.562 \\
(0.774) * * *\end{array}$ & $\begin{array}{l}-2.576 \\
(0.778)^{* * *}\end{array}$ & $\begin{array}{l}-2.593 \\
(0.766) * * *\end{array}$ & $\begin{array}{l}-5.922 \\
(0.823)^{* * *}\end{array}$ & $\begin{array}{l}-5.939 \\
(0.820)^{* * *}\end{array}$ & $\begin{array}{l}-5.933 \\
(0.818)^{* * *}\end{array}$ \\
\hline Observations & 6197 & 6197 & 6197 & 6197 & 6197 & 6197 \\
\hline Log Likelihood & -2373.00 & -2373.24 & -2373.33 & -1848.2039 & -1848.32 & -1848.48 \\
\hline
\end{tabular}


Table 4: Conditional Fixed Effects Negative Binomial Regressions, 1927, 1938 and 1946

Dependent variable is either the number of laboratories in county $i$ in year $t$, or the total employment of laboratories in the county.
(1)
(2)
(3)
(4)
(5)
(6)

\begin{tabular}{|c|c|c|c|c|}
\hline Laboratories & Laboratories & Laboratories & $\begin{array}{c}\text { R\&D } \\
\text { Workers }\end{array}$ & $\begin{array}{c}\text { R\&D } \\
\text { Workers }\end{array}$ \\
\hline
\end{tabular}

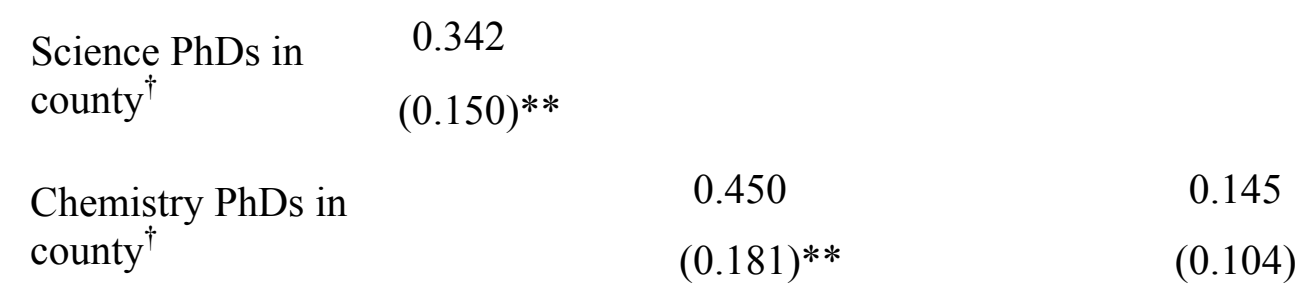

Chemistry PhDs in

county

0.038

Distance-weighted

0.188

0.186

Chemistry PhDs

$(0.065)^{* * *}$

$(0.012) * * *$

\begin{tabular}{|c|c|c|c|c|c|c|}
\hline Population $^{\dagger}$ & $\begin{array}{l}-3.690 \\
(1.337)^{* * *}\end{array}$ & $\begin{array}{l}-3.617 \\
(1.337)^{* * *}\end{array}$ & $\begin{array}{l}-2.042 \\
(1.566)\end{array}$ & $\begin{array}{c}0.624 \\
(0.607)\end{array}$ & $\begin{array}{c}0.471 \\
(0.623)\end{array}$ & $\begin{array}{r}0.414 \\
(0.630)\end{array}$ \\
\hline
\end{tabular}

$\begin{array}{ccccccc}\text { Manufacturing }^{\dagger} & 0.436 & 0.446 & 0.257 & 0.532 & 0.529 & 0.460 \\ & (0.272) & (0.272) & (0.270) & (0.127)^{* * *} & (0.127)^{* * *} & (0.128)^{* * *}\end{array}$

\begin{tabular}{lrrrrrr} 
Constant & 2.237 & 2.121 & 2.597 & -5.507 & -5.428 & -5.261 \\
& $(1.702)$ & $(1.690)$ & $(1.789)$ & $(0.603) * * *$ & $(0.600)^{* * *}$ & $(0.596)^{* * *}$ \\
\hline $\begin{array}{l}\text { Observations } \\
\begin{array}{l}\text { Number of groups } \\
\text { (county state) }\end{array}\end{array}$ & 788 & 788 & 781 & 644 & 644 & 640 \\
Log Likelihood & -411.70 & -411.18 & -404.82 & -821.30 & -817.68 & -812.79
\end{tabular}

${ }^{\dagger}$ in logs

Year dummies included

Standard errors in parentheses

$*$ significant at $10 \% ; * *$ significant at $5 \%$;** significant at $1 \%$ 
Table 5 Determinants of Cooperative Research

Logit estimates

Dependent variable: $\mathrm{COOP}=1$ if firm has cooperative agreement with University

(3)

(4)

(5)

\begin{tabular}{|c|c|c|c|c|c|}
\hline Science $\mathrm{PhDs}^{\dagger}$ & $\begin{array}{l}0.376^{* * *} \\
(0.061)\end{array}$ & & & & \\
\hline Chemistry $\mathrm{PhDs}^{\dagger}$ & & $\begin{array}{l}0.503 \\
(0.084)^{* * *}\end{array}$ & $\begin{array}{l}0.652 \\
(0.135)^{* * *}\end{array}$ & $\begin{array}{c}0.517 \\
(0.221)^{* *}\end{array}$ & $\begin{array}{l}0.574 \\
(0.235)^{* *}\end{array}$ \\
\hline $\mathrm{R} \& \mathrm{D} \operatorname{staff}^{\dagger}$ & $\begin{array}{l}0.186^{* *} \\
(0.082)\end{array}$ & $\begin{array}{l}0.177 \\
(0.082)^{* *}\end{array}$ & $\begin{array}{l}-0.005 \\
(0.103)\end{array}$ & $\begin{array}{l}-0.005 \\
(0.104)\end{array}$ & $\begin{array}{c}0.181 \\
(0.084)^{* *}\end{array}$ \\
\hline Age & & & $\begin{array}{c}0.011 \\
(0.006)^{*}\end{array}$ & $\begin{array}{c}0.008 \\
(0.007)\end{array}$ & \\
\hline Age $\mathrm{X}$ chemistry $\mathrm{PhDs}^{\dagger}$ & & & & $\begin{array}{c}0.005 \\
(0.006)\end{array}$ & \\
\hline $\mathrm{R} \& \mathrm{D}^{\dagger} \mathrm{X}$ chemistry $\mathrm{PhDs}^{\dagger}$ & & & & & $\begin{array}{l}-0.015 \\
(0.045)\end{array}$ \\
\hline Year $=1946$ & $\begin{array}{l}1.495 * * * \\
(0.274)\end{array}$ & $\begin{array}{c}1.474 \\
(0.273)^{* * *}\end{array}$ & & & $\begin{array}{c}1.485 \\
(0.276)^{* * *}\end{array}$ \\
\hline Constant & $\begin{array}{l}-2.158^{* * *} \\
(0.310)\end{array}$ & $\begin{array}{l}-2.090 \\
(0.305)^{* * *}\end{array}$ & $\begin{array}{l}-0.364 \\
(0.358) \\
\end{array}$ & $\begin{array}{l}-0.301 \\
(0.378) \\
\end{array}$ & $\begin{array}{l}-2.115 \\
(0.322)^{* * *}\end{array}$ \\
\hline Observations & 528 & 528 & 351 & 351 & 528 \\
\hline Log likelihood & -319.17 & -319.75 & -220.11 & -219.87 & -319.70 \\
\hline
\end{tabular}


Table 6: New Chemical Engineering programs, 1937-47

Dependent variable $=1$ if the university began offering degrees in chemical engineering between 1937 and 1947

(1)

$\begin{array}{ll}0.249 & 0.285 \\ (0.113)^{* *} & (0.115)^{* *}\end{array}$

Pharma R\&D employment in 1938

Pharma labs in 1938$$
(0.113)^{* *}
$$

$(0.115)^{* *}$

Manufacturing in 1939

Population in 1940

Growth of Population, 1940-1950

Growth of Manufacturing, 1939-

1947

$\begin{array}{llll}0.004 & -0.273 & -0.045 & -0.393 \\ (0.460) & (0.514) & (0.469) & (0.536)\end{array}$

$$
-0.187
$$$$
\text { (0.609) }
$$

0.171

(0.643)

$-0.023$

(0.604)

1.638

(1.092)

$\begin{array}{ll}0.008 & 0.009 \\ (0.004)^{* *} & (0.004)^{* *}\end{array}$

$-0.817$

(0.642)

$-0.265$

$(0.137)^{*}$

Growth of pharma labs, 1938-1946

Growth in R\&D employment, 1938-1946

\begin{tabular}{lcccc} 
Constant & -1.429 & -4.261 & -3.005 & -5.834 \\
& $(4.916)$ & $(5.135)$ & $(4.845)$ & $(5.134)$ \\
\hline Observations & 867 & 867 & 867 & 867
\end{tabular}

Robust standard errors in parentheses

* significant at $10 \%$; * significant at 5\%; * significant at $1 \%$ 
Table 7a: 2SLS instrumental variables estimates

(1)

(2)

(3)

(4)

\begin{tabular}{lcccc} 
& Number of labs & Number of labs & $\begin{array}{c}\text { R\&D } \\
\text { employment }\end{array}$ & $\begin{array}{c}\text { R\&D } \\
\text { employment }\end{array}$ \\
\hline Chemistry PhDs $^{\dagger}$ & 0.083 & & 0.162 & \\
Science PhDs $^{\dagger}$ & $(0.038)^{* *}$ & & $(0.110)$ & \\
& & 0.055 & & 0.113 \\
Population $^{\dagger}$ & 1.350 & $(0.025)^{* *}$ & & $(0.073)$ \\
& $(0.143)^{* * *}$ & $(0.142)^{* * *}$ & $(0.387)^{* * *}$ & 3.340 \\
Manufacturing $^{\dagger}$ & -0.009 & -0.009 & -0.009 & $-0.385)^{* * *}$ \\
& $(0.003)^{* * *}$ & $(0.003)^{* * *}$ & $(0.009)$ & $(0.009)$ \\
Constant & 0.037 & 0.039 & 0.027 & 0.030 \\
& $(0.009)^{* * *}$ & $(0.009)^{* * *}$ & $(0.031)$ & $(0.031)$ \\
\hline Observations & 9304 & 9304 & 9304 & 9304 \\
First-stage F stat & 64.4 & 76.29 & 64.4 & 76.29 \\
Over-id test stat & 1.458 & 1.613 & 0.006 & 0.000 \\
p-value & 0.227 & 0.204 & 0.939 & 0.989
\end{tabular}

Table 7b: GMM (non-linear 2SLS) instrumental variables estimates Number of labs Number of labs

$\mathrm{R} \& \mathrm{D}$

$\mathrm{R} \& \mathrm{D}$ employment employment

\begin{tabular}{|c|c|c|c|c|}
\hline Chemistry PhDs ${ }^{\dagger}$ & $\begin{array}{l}0.326 * * * \\
(0.136)\end{array}$ & & $\begin{array}{c}0.298 \\
(0.405)\end{array}$ & \\
\hline Science $\mathrm{PhDs}^{\dagger}$ & & $\begin{array}{l}0.225^{* *} \\
(0.097)\end{array}$ & & $\begin{array}{c}0.240 \\
(0.260)\end{array}$ \\
\hline Manufacturing $^{\dagger}$ & $\begin{array}{l}0.827 * * * \\
(0.097)\end{array}$ & $\begin{array}{l}0.820 * * * \\
(0.096)\end{array}$ & $\begin{array}{l}0.830 * * * \\
(0.155)\end{array}$ & $\begin{array}{l}0.831 * * * \\
(0.151)\end{array}$ \\
\hline Population $^{\dagger}$ & $\begin{array}{l}-0.258 \\
(0.407)\end{array}$ & $\begin{array}{l}-0.212 \\
(0.3919)\end{array}$ & $\begin{array}{l}-0.479 \\
(0.935)\end{array}$ & $\begin{array}{l}-0.535 \\
(0.863)\end{array}$ \\
\hline Constant & $\begin{array}{l}-5.776 * * * \\
(0.460)\end{array}$ & $\begin{array}{l}-5.733 * * * \\
(0.454)\end{array}$ & $\begin{array}{l}-3.483 * * * \\
(0.774)\end{array}$ & $\begin{array}{l}-3.481 * * * \\
(0.755)\end{array}$ \\
\hline Observations & 9304 & 9304 & 9304 & 9304 \\
\hline Over-ID test & 0.247 & 0.192 & 1.461 & 1.359 \\
\hline $\mathrm{p}$-value & 0.619 & 0.661 & 0.227 & 0.244 \\
\hline
\end{tabular}




\section{Appendix A: Introduction from the 1927 National Research Council survey}

"The continued demand for information regarding industrial research laboratories has made it seem advisable to issue a second revision of the list originally published in Number 2 and revised in Number 16 of the Bulletin of the National Research Council. The original publication, compiled in 1920 by Mr. Alfred D. Flinn, Secretary of the Engineering Foundation, listed about 300 industrial laboratories. The first revision prepared in August 1921, by Miss Ruth Cobb of the Research Information Service, listed 526 laboratories. The present revision contains data for 1,000 laboratories.

As in the earlier lists, all information given in this publication has been obtained directly by correspondence and statements are based upon information supplied by laboratories....In preparing the mailing list of new companies to which questionnaires should be sent, the Research Information Service sought the cooperation of the secretaries of the local divisions of the American Chemical Society, the American Institute of Electrical Engineers, the American Society of Civil Engineers and the American Society of Mechanical Engineers; most of the secretaries supplied a list of the industrial laboratories in their community..." 
Appendix B: Data on Morrill Act land grants

\begin{tabular}{|c|c|c|c|}
\hline Cornell U & 1863 & 990,000 & $1,688,576^{*}$ \\
\hline Michigan State & 1863 & 240,000 & 991,673 \\
\hline Oklahoma Agr and Mech Coll & 1890 & 350,000 & $835,637 * *$ \\
\hline U California & 1866 & 150,000 & 732,233 \\
\hline Iowa State Coll & 1862 & 240,000 & 686,817 \\
\hline U Illinois & 1867 & 480,000 & 648,442 \\
\hline U Minnesota & 1863 & 120,000 & 579,430 \\
\hline U Nebraska & 1867 & 90,800 & 560,072 \\
\hline Montana State Coll & 1889 & 140,000 & 533,148 \\
\hline Kansas State Agr Coll & 1863 & 97,682 & 491,746 \\
\hline North Dakota Agr Coll & 1889 & 130,000 & 455,924 \\
\hline Penn State Coll & 1863 & 780,000 & 439,186 \\
\hline U Missouri & 1863 & 330,000 & 363,441 \\
\hline Ohio State U & 1864 & 630,000 & 340,906 \\
\hline U Wisconsin & 1863 & 240,000 & 303,594 \\
\hline Virginia Agr and Mech Coll & 1870 & 300,000 & 285,000 \\
\hline U Tennessee & 1868 & 300,000 & 271,875 \\
\hline State Coll of Washington & 1889 & 900,000 & 247,608 \\
\hline Georgia State Coll Agri & 1866 & 270,000 & 242,202 \\
\hline Massachusetts Agr Coll & 1863 & 360,000 & 236,287 \\
\hline Alabama Polytechnic & 1867 & 240,000 & 216,000 \\
\hline Purdue U & 1865 & 390,000 & 212,238 \\
\hline Oregon Agr Coll & 1868 & 90,000 & 202,113 \\
\hline Agr Coll Utah & 1888 & 200,000 & 194,136 \\
\hline Mississippi Agr \& Mech Coll & 1866 & 210,000 & 188,028 \\
\hline Colorado Agr College & 1879 & 916,000 & 185,956 \\
\hline Louisiana State U & 1869 & 210,000 & 182,630 \\
\hline Agr \& Mech Coll of Texas & 1866 & 180,000 & 174,000 \\
\hline U Kentucky & 1863 & 330,000 & 164,960 \\
\hline North Carolina State U & 1889 & 270,000 & 135,000 \\
\hline Clemson Agricultural Coll & 1868 & 180,000 & 130,500 \\
\hline U Idaho & 1890 & 90,000 & 129,615 \\
\hline South Dakota State Coll & 1889 & 160,000 & 128,804 \\
\hline U Vermont & 1862 & 150,000 & 122,626 \\
\hline U Maine & 1863 & 210,000 & 116,359 \\
\hline Rutgers U & 1863 & 210,000 & 115,945 \\
\hline U Maryland & 1864 & 210,000 & 112,504 \\
\hline U Nevada & 1866 & 90,000 & 107,363 \\
\hline West Virginia $U$ & 1863 & 150,000 & 90,000 \\
\hline Conn Agr Coll & 1862 & 90,000 & 83,000 \\
\hline U Delaware & 1867 & 90,000 & 83,000 \\
\hline U Florida & 1870 & 90,000 & 80,000 \\
\hline U New Hampshire & 1863 & 150,000 & 80,000 \\
\hline U Wyoming & 1889 & 90,000 & 73,355 \\
\hline Rhode Island State Coll & 1863 & 120,000 & 50,000 \\
\hline Alaska Agr Col \& School of Mines & 1929 & 336,000 & \\
\hline U Arizona & 1910 & 150,000 & \\
\hline U Arkansas & 1864 & 150,000 & \\
\hline \multicolumn{4}{|l|}{ U Hawaii } \\
\hline \multicolumn{4}{|l|}{ MIT } \\
\hline New Mexico Coll of Agr \& Mech & 1898 & 250000 & \\
\hline
\end{tabular}

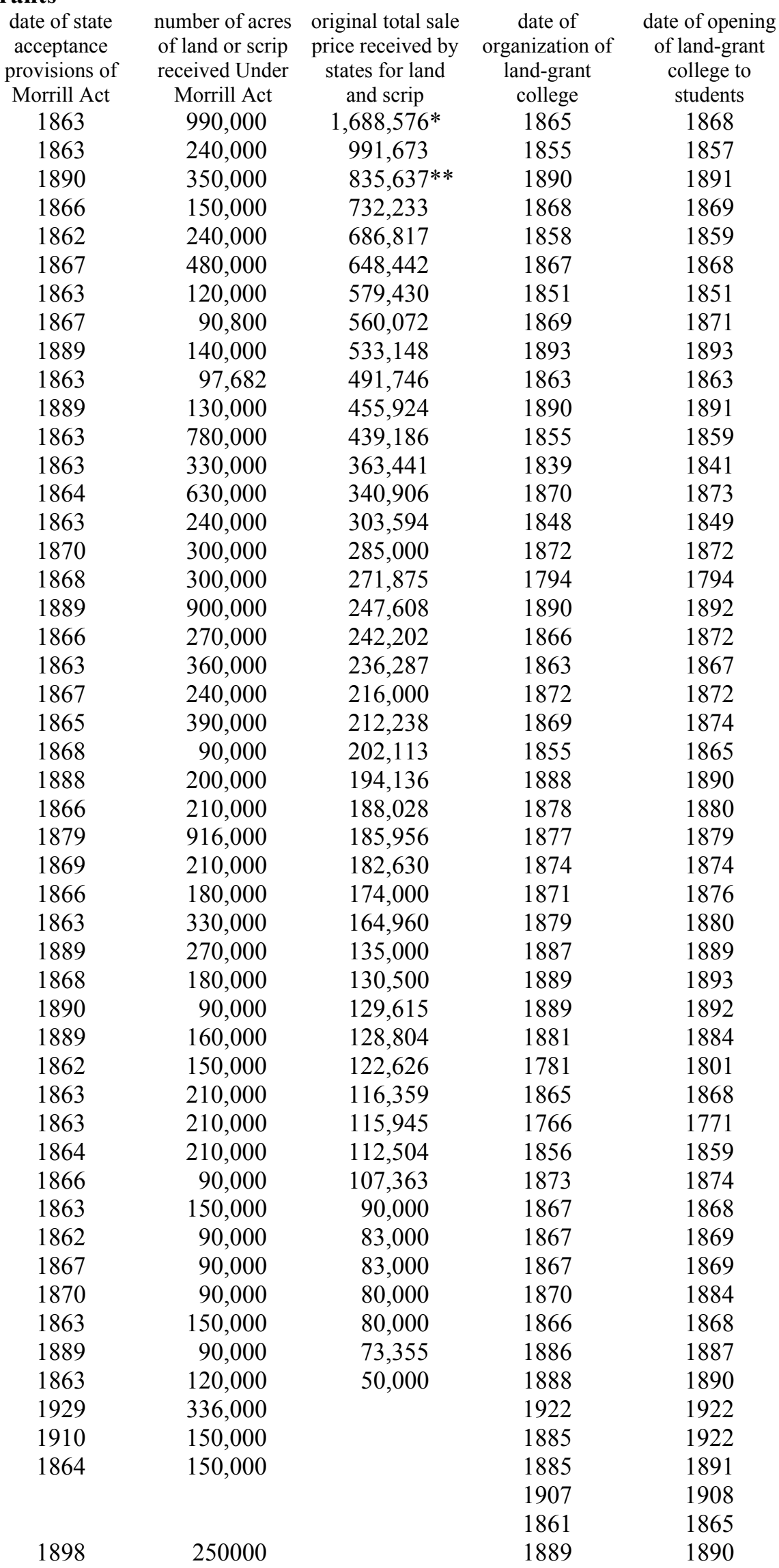


Figure 1: Founding Dates of Public Universities

(using data from 1924 Biennial of Education data Sample)

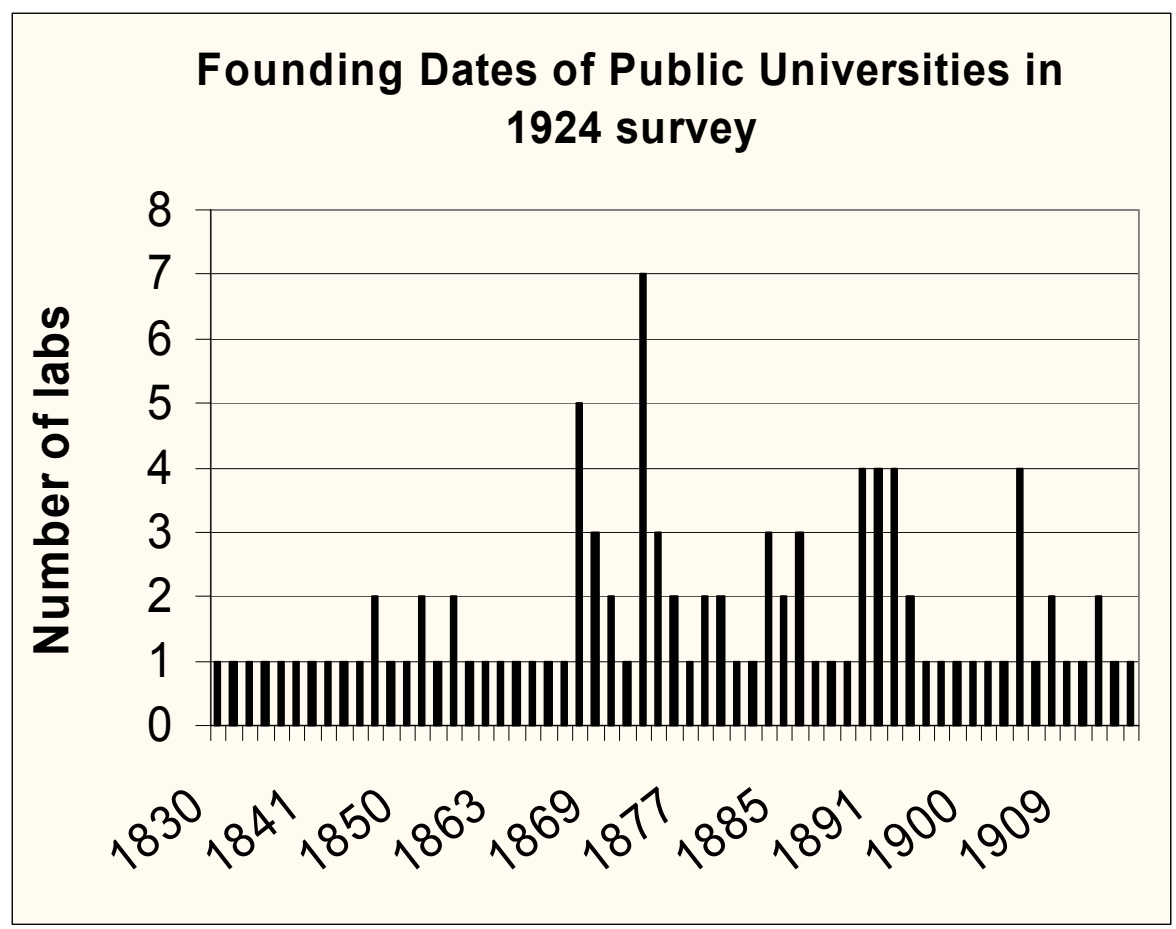

Figure 2: Founding Dates of Private Universities

(using data from 1924 Biennial of Education data Sample)

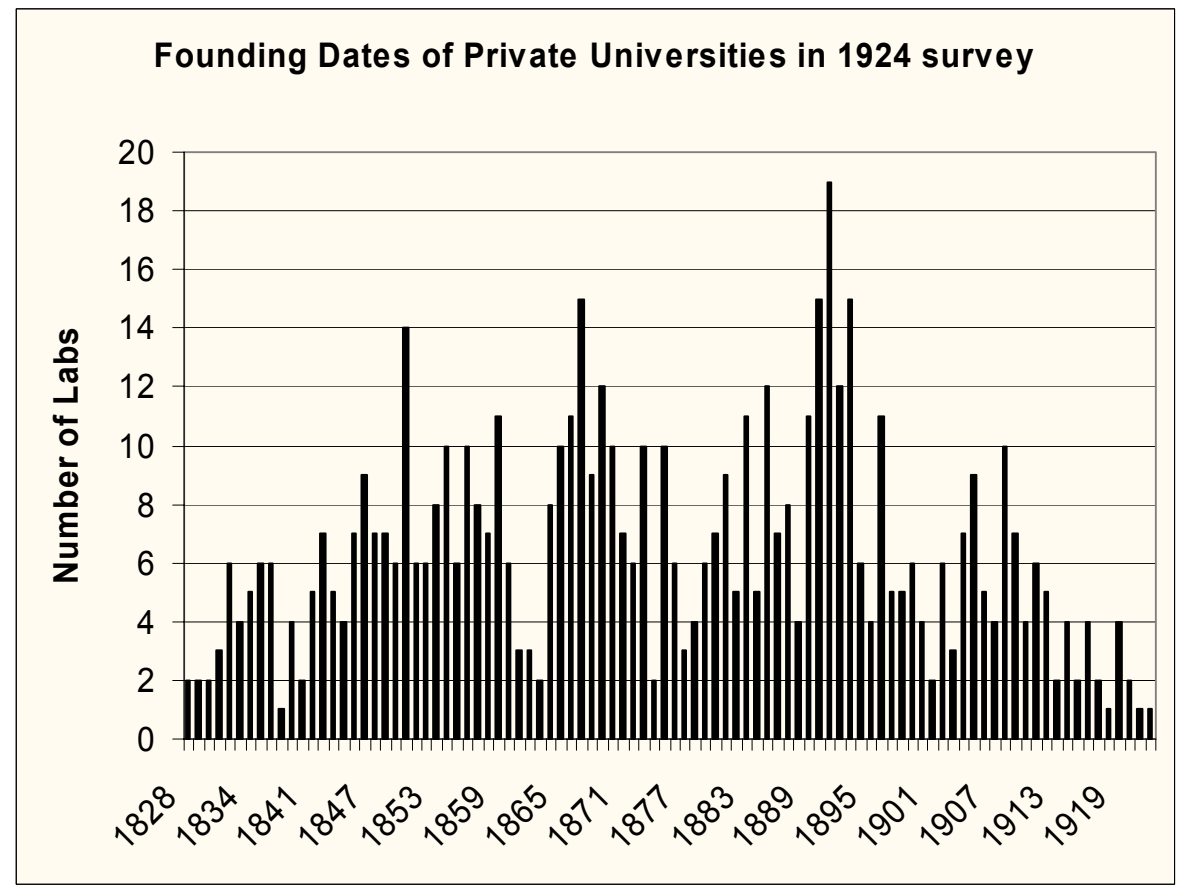


Figure 3: Founding Dates of Industrial Research Labs

(using data from 1946 National Research Council data Sample)

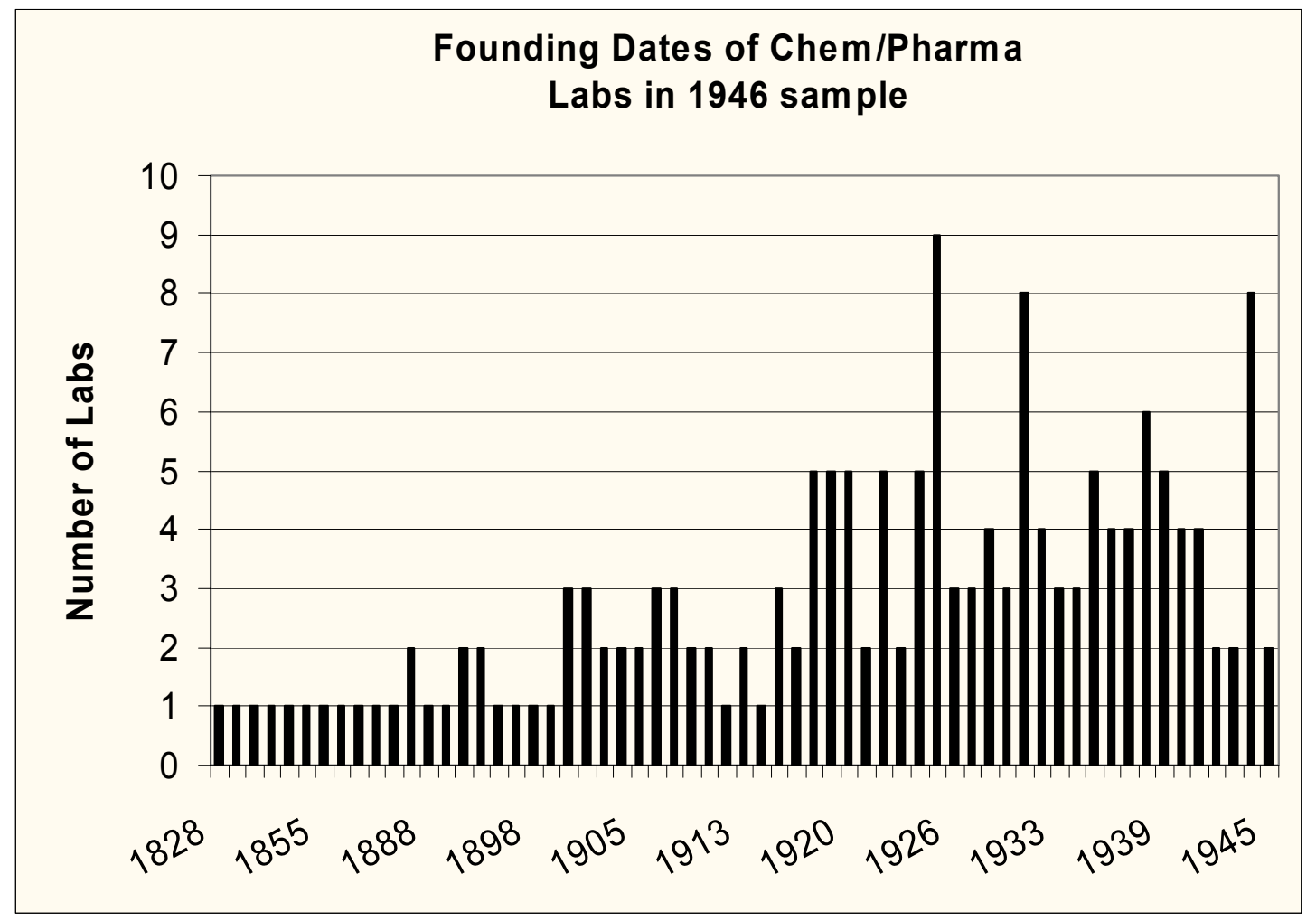


Figure 4: The Location of Industrial Research in the United States, 1927

(Sizes of circles indicate the number of labs in the city/town)

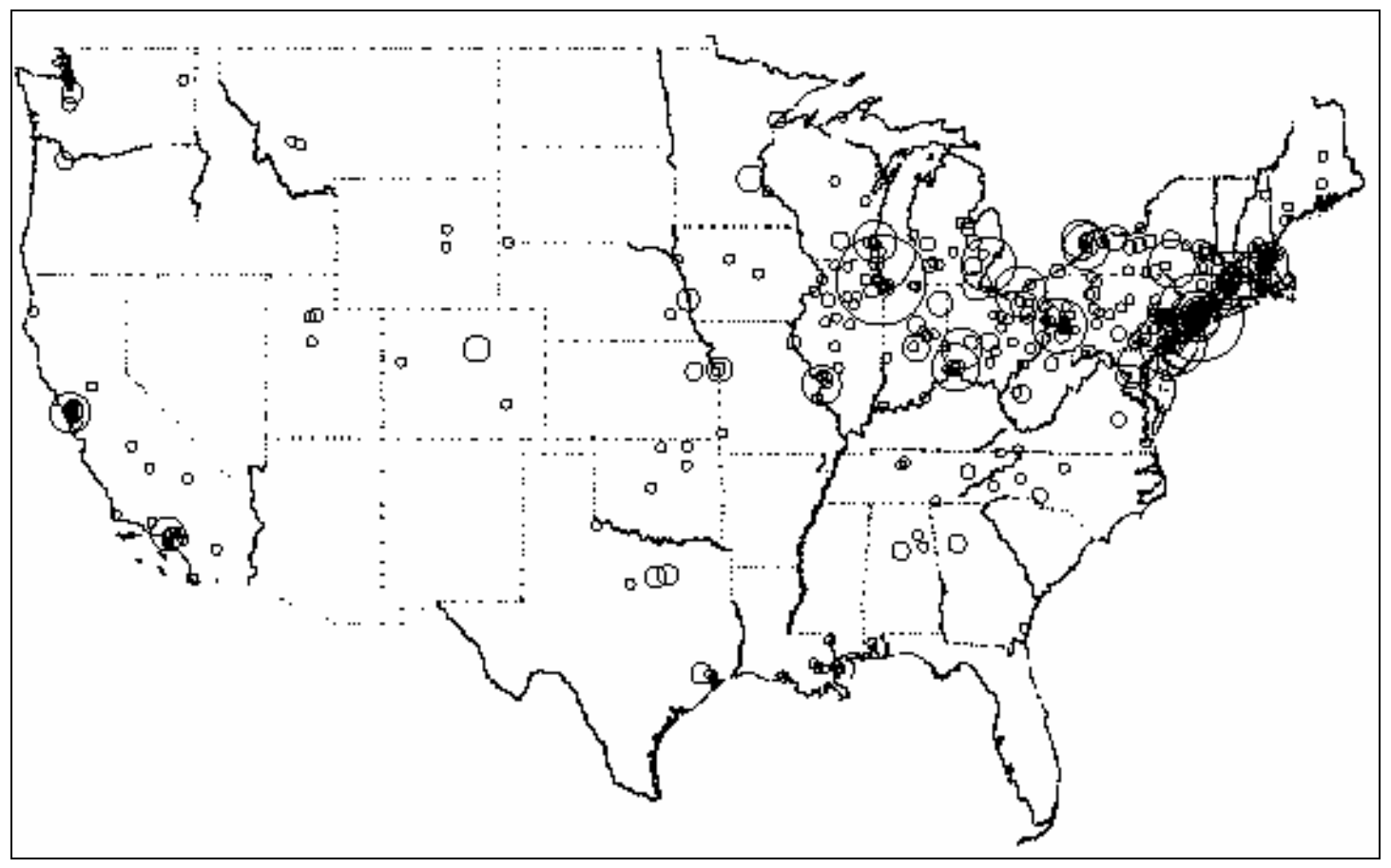

Figure 5: PhD-granting institutions, weighted by degrees granted, 1928-37

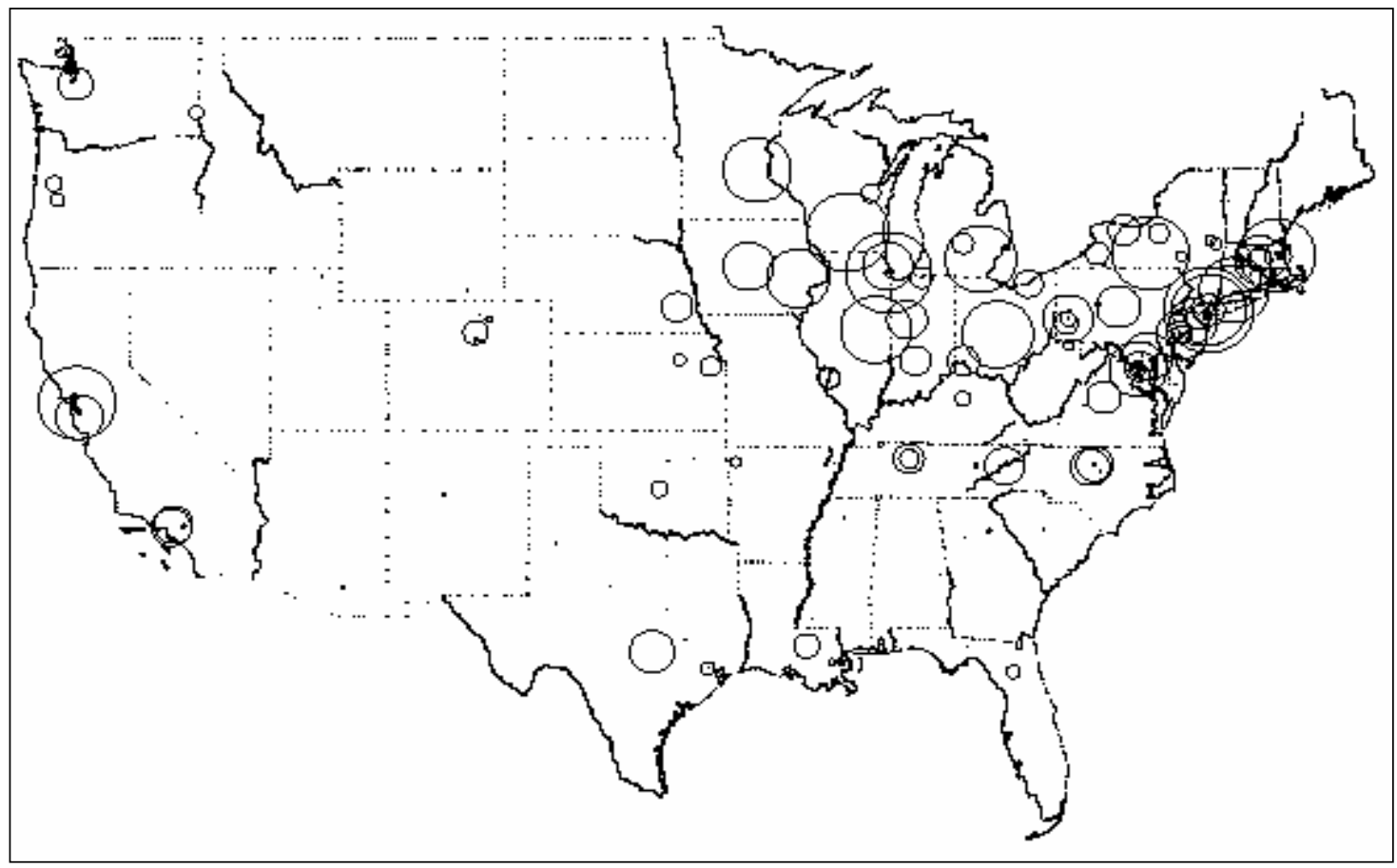

